\title{
Tanzanian Myxomycetes: first survey
}

\author{
MARJA HÄRKÖNEN and TINA SAARIMÄKI
}

\begin{abstract}
HÄRKÖNEN, M. \& SAARIMÄKI, T. 1991: Tanzanian Myxomycetes: first survey. Karstenia 31:31-54.

During the rainy seasons in May and December 1988 and in December 1989, Myxomycetes were collected in northeastern and southern Tanzania, with 53 species found. According to the literature, all are new to Tanzania, and the following seven are new to Africa: Didymium bahiense Gottsb., Paradiachea cylindrica (Bilgram) Hertel, Physarum notabile Macbr., P. psittacinum Ditmar, $P$. superbum Hagelst., Tubifera bombarda (Berk. \& Br.) Martin, and T. microsperma (Beck. \& Curt.) Martin. A lectotype for Arcyria globosa Schw. is selected. Myxomycetes were more abundant in the montane forest belt than at other elevations, and no significant difference could be noticed in species composition between the two rainy seasons, May and December. Species belonging to the order Licheales were found only on decaying wood, and of the Physarales the majority of the specimens were found on litter.
\end{abstract}

Key words: Africa, fungi, Myxomycetes, Tanzania, tropics

Marja Härkönen \& Tïna Saarimäki, Department of Botany, University of Helsinki, Unioninkatu 44, SF-00170 Helsinki, Finland

\section{Introduction}

The fungi of Africa have not yet been researched effectively. In the course of deforestation, fungi depending on trees in particular become threatened and many of these fungi have not yet been discovered. In Tanzania the Myxomycetes, for example, have remained totally unexplored.

\section{Material and methods}

Three excursions about four weeks in length were made to Tanzania, all in the rain season: May 1988, December 1988, and December 1989. Several vegetation types from rain forest to semidesert and high mountains were visited. The main activity was, however, directed to the montane forests of northeastern Tanzania. This research area is shown in Maps 1 and 2.

In the field, moist cavities in trees, decaying logs, and litter were searched to find mature myxomycete specimens. Also bark from living trees was collected for moist chamber cultures, but the results of those will be presented later. The specimens are deposited in the Botanical Museum, University of Helsinki $(\mathrm{H})$, Finland, but a set of duplicates will later be sent to the University of Dar es Salaam (DSM) and/or the Sokoine University, Tanzania, according to their interest in the material. Most specimens are preserved also as permanent slides in Hoyer's medium (Martin \& Alexopoulos 1969).

\section{The species of Myxomycetes}

As no earlier information about Tanzanian Myxomycetes exists, all species are briefly described here on the basis of material found. Nomenclature follows, with few exceptions, Martin \& Alexopoulos (1969). When other references are used, synonyms are mentioned.

Species are determined and their distribution checked with the aid of the literature listed in the references. In the list of specimens, the codes of collection localities (see Map 2) are followed by the collection numbers of Marja Härkönen or Tiina Saarimäki (TS). 


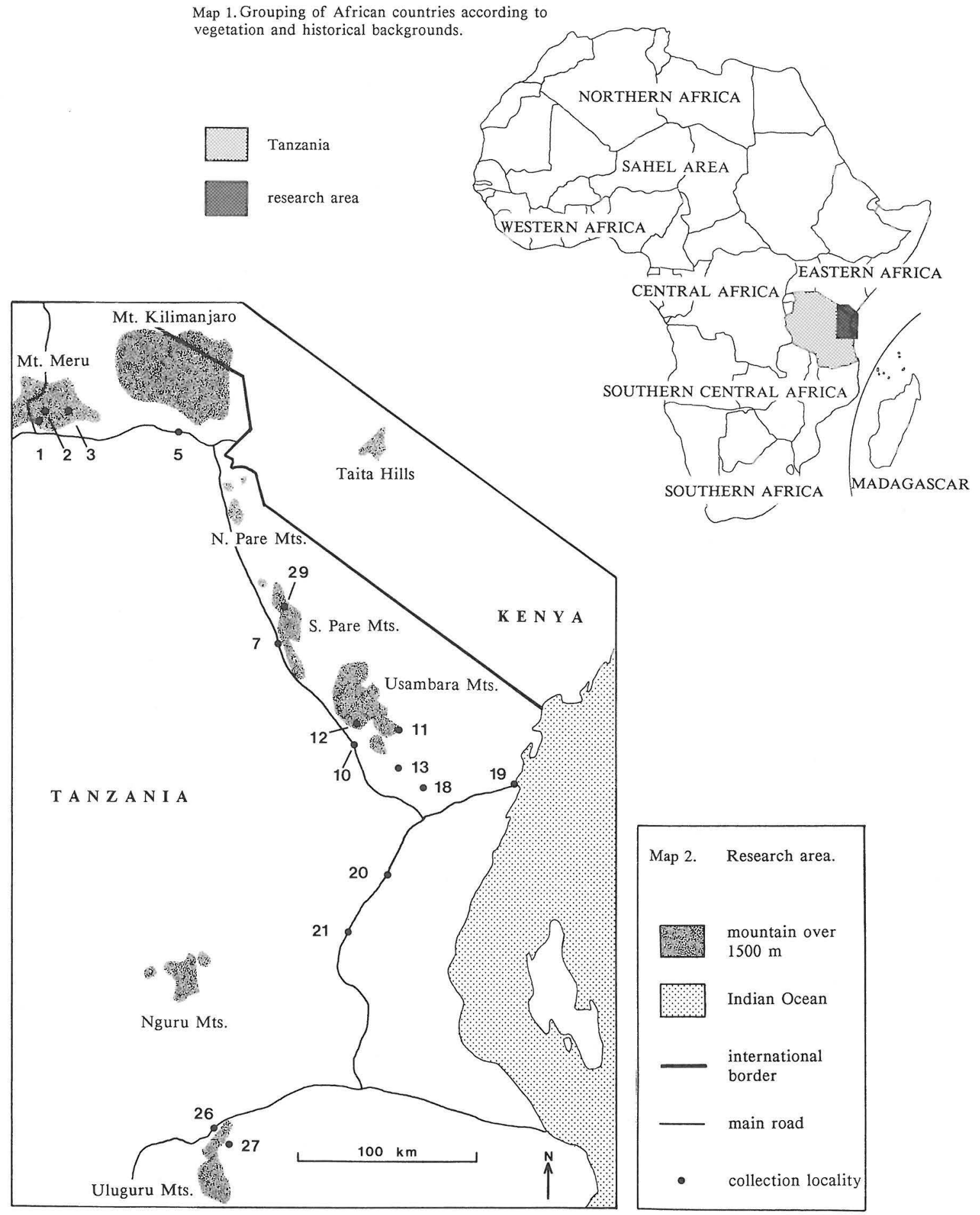


Arcyria affinis Rost. emend. Nann.-Brem.

11: 3657. Specimen from montane forest. On decayed wood.

Sporangia gregarious in dense clusters, stipitate, ovoid to cylindrical, brilliantly tomato-red. Total height after expansion up to $7 \mathrm{~mm}$. Peridium fugacious; calyculus deep, shining, asymmetric, papillate-reticulate inside by transmitted light. Stipe about $0.5 \mathrm{~mm}$ long, black, furrowed, filled with spore-like cells, $12-15 \mu \mathrm{m}$ in diam. Hypothallus very thin, shining, common to a colony. Capillitium attached only to the apex of stalk, with cogs and halfrings in loose spiral, about $3 \mu \mathrm{m}$ thick when ornamentals excluded. Spores red in mass, pink, nearly hyaline by transmitted light, nearly smooth with some scattered warts, by oil immersion also minutely punctate, $6.5-$ 7-7.5 $\mu \mathrm{m}$.

Martin \& Alexopoulos (1969) placed A. affinis in the list of excluded and doubtful species. NannengaBremekamp (1968) recognized the species, emending the description, and Robbrecht (1974) follows her. The present specimen fits well Robbrecht's description in its tomato-red colour, long-cylindrical shape of expanded capillitium, asymmetric calyculus and small size of spore-like cells in stipe.

\section{Arcyria cinerea (Bull.) Pers.}

2: $3440,3444,3510,3724,3729,3737,3744$, TS 487. 3: 3437 , 3522. 11: $3426,3429,3646,3651,3655,3659,3666,3671$, 3674, 3688, 3699, TS 403, TS 442. 18: 3409, 3476, 3490, 3514. $29: 3617,3618$. Five collections from submontane rain forests, twenty-three from montane forests and one from Ericaceous zone. On decayed wood and litter. Cosmopolitan. This is one of the most common Myxomycetes in both tropical and temperate regions. Reported from many parts of Africa, but no previous records from eastern Africa.

Sporangia scattered to gregarious, single or in small clusters, stipitate, ovoid to subcylindric, pale grey or beige. Total height $1.5-6 \mathrm{~mm}, 0.2-0.8 \mathrm{~mm}$ in diameter. Peridium fugacious; calyculus small, distinct, concolorous, shiny, radially sulcate below. Stipe slender, up to $3 \mathrm{~mm}$ tall, pallid to black, shiny, filled with large, spore-like cells. Hypothallus concolorous with the stipe, in some specimens confluent. Capillitium firmly attached to the calyculus, elastic, threads in the upper part, ca. $2 \mu \mathrm{m}$ in diameter, densely sharp-spinulose and those of the lower part thicker, up to $6 \mu \mathrm{m}$, and with short spines or at the base nearly smooth. Spores grey in mass, hyaline by transmitted light, 6-6.6-9 $\mu \mathrm{m}$ in diam., nearly smooth with a few scattered or grouped warts.

\section{Arcyria denudata (L.) Wettst.}

$2: 3705,3706,3732,3738,3741,3743,3758,3762$, TS 457 , TS 469, TS 488, TS 493. 3: $3472,3518.11: 3434,3654,3676,3683$, 3690 , 3694, TS 412, TS 428a. 18: 3413. 29: 3615. One collection from submontane rain forest, twenty-three from montane forests. All, except one, on wood. Cosmopolitan. With Arcyria cinerea one of the most common species. Reported from many parts of Africa. No earlier records from eastern Africa.

Sporangia gregarious to crowded, stipitate, cylindric, tapering upward, crimson or rust-red, fading to brownish, $0.8-1.8 \mathrm{~mm}$ in diameter when expanded. Total height 2-7 mm. Peridium evanescent. Calyculus small, plicate, concolorous, shining, trumpetshaped. Stipe up to $2 \mathrm{~mm}$ high, slender, brownish black, shining, furrowed, filled with spore-like cells. Hypothallus small. Capillitium a continuous net, expanding, firmly attached to the whole inner surface of the calyculus, consisting of threads marked with cogs and half-rings arranged in a loose spiral, without ornamentation, ca $3.5 \mu \mathrm{m}$ in diameter. Spores reddish in mass, almost colourless by transmitted light, nearly smooth, with a few scattered warts $6-6.6-9 \mu \mathrm{m}$.

One specimen (3472) differs from the others in having a saucer-shaped calyculus and greatly expanding capillitium like in Arcyria incarnata (Pers.) Pers. Several attachments of the capillitium to the calyculus and the length of the stipe $(0.8-1 \mathrm{~mm})$ of that specimen deviate, however, from the descriptions of $A$. incarnata given in many publications (Martin \& Alexopoulos 1969, Lister 1925, Robbrecht 1974, Farr 1976). This specimen seems to be an intermediate form.

Arcyria globosa Schw.

Figs. 1-2

2: 3446. Collection from montane forest. On fallen leaves. Found in temperate, subtropical and tropical regions. Earlier reported from western and southern central Africa.

Sporangia scattered to gregarious, stipitate, globose, pale yellowish grey. Total height $1.5-2 \mathrm{~mm}$, diameter $0.5-1 \mathrm{~mm}$. Peridium partly fugacious, leaving the lower half a deep goblet-shape calyculus, papillose, concentrically wrinkled. Stipe yellowish, shining, slightly rugose, filled with angular, sporelike cells, becoming darker towards the base, 0.5

Map 1 (Left above). Grouping of African countries according to vegetation and historical background.

Map 2 (Left below). Research area. 

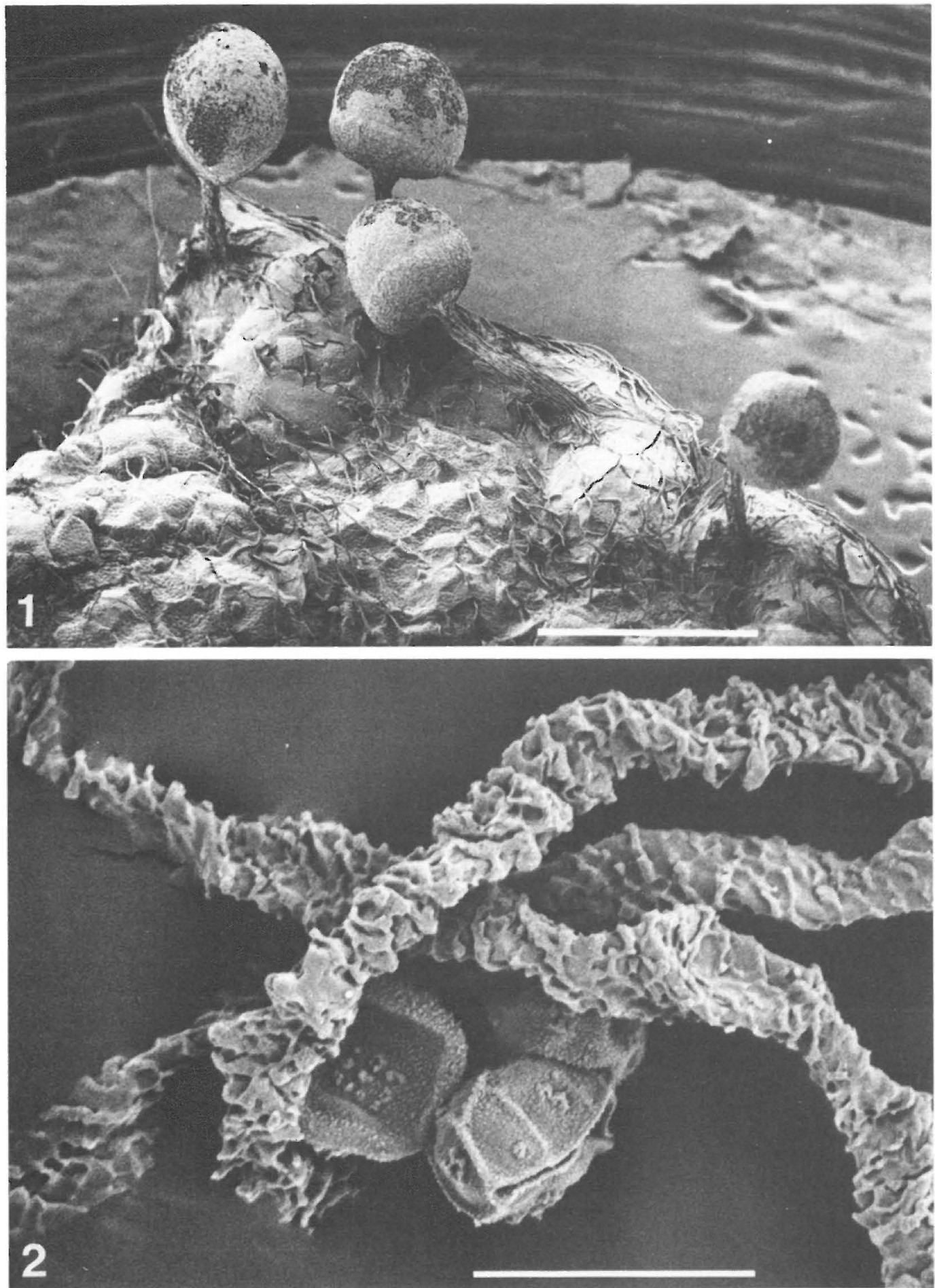

Figs. 1-2. SEM-photos of Arcyria globosa (No. 3446). 1. Sporangia on fallen leaf of Hagenia abyssinica. Bar $=1 \mathrm{~mm}$. 2. Capillitial filaments with sculptures arranged in spirals, and spores. Bar $=10 \mu \mathrm{m}$. Photo Vanamo Salo. 
$1 \mathrm{~mm}$ tall. Hypothallus small but distinct, discoid, brown, having some refuse matter inside. Inelastic capillitial net firmly attached to the calyculus, consisting of almost hyaline colourless filaments, $3-5 \mu \mathrm{m}$ in diameter, marked with warts and nodular swellings arranged more or less distinctly in spirals. Spores nearly colourless, nearly smooth with a few groups of scattered verrucae, 7.3-8.5-10 $\mu \mathrm{m}$ in diameter.

The capillitium (Fig. 2) looks very different from the one illustrated in Martin \& Alexopoulos (1969: fig. 85). The original description is very short (Schweinitz 1822). As no type specimen has been named, our specimen was compared with the original material of Schweinitz. Two packets of Arcyria globosa were obtained from the Schweinitz Herbarium in the Academy of Natural Sciences of Philadelphia $(\mathrm{PH})$. One of these original collections was found to contain no sporangia. The other, labelled "Arcyria globosa Schw., Bethlehem, Syn. \# 2340" (from Pennsylvania, U.S.A.), is selected here as the lectotype. The concentric wrinkles and the papillose inner side of the calyculus and also the characteristics of the capillitium and spores of the lectotype are identical with the present material. Good figures of A. globosa are presented by Rammeloo (1986, pl. 116).

In all major floras of Myxomycetes, dead burs and leaves of chesnut are considered typical substrate of Arcyria globosa. The present specimen grew as a rich colony on fallen leaves of Hagenia abyssinica Gmel. (Rosaceae).

\section{Arcyria insignis Kalchbr. \& Cooke}

$2: 3495,3736,3742,3755$, TS 524.11:3431.18: $3480.27: 3427$. One collection from lowland rain forest, one from submontane rain forest, six from montane forests. One on litter, the others on decayed wood. Cosmopolitan. Reported from many parts of Africa, no previous records from eastern Africa.

Sporangia gregarious or in small clusters, stipitate, cylindrical, different tones of red from bright pink to brownish or rosy beige. Total height 1.5$3.0 \mathrm{~mm}, 0.7-1 \mathrm{~mm}$ in diameter when expanded. Peridium evanescent, except small calyculus. Calyculus shallow, trumpet-shaped, membranous, shining, plicate, spinulose and in some specimens also reticulate inside. Stipe up to $1 \mathrm{~mm}$ tall, reddish to almost black, furrowed, filled with spore-like cells (10-25 $\mu \mathrm{m}$ at the base). Hypothallus continuous, concolorous with stipe or lighter, shining. Capillitium a dense, elastic network of slender threads, $2-4 \mu \mathrm{m}$ in diameter, firmly attached to the whole calyculus. Threads marked with transverse bands, half-rings and spines arranged in loose spirals which almost double the diameter of each thread. Inside calyculus the net is nearly smooth. Spores pink in mass, almost hyaline, pink to yellowish by transmitted light, nearly smooth with a few scattered and inconspicuous warts, 6-6.7-8 $\mu \mathrm{m}$.

The colour of the capillitium is soluble in alcohol so that preparations turn nearly hyaline on the permanent slide.

\section{Arcyria obvelata (Oeder) Onsberg}

syn. A. nutans (Bull.) Grev.

2: 3756, TS 530. 11: 3695. All collections from montane forests on decayed wood. Cosmopolitan. Reported from several parts of Africa.

Sporangia gregarious, cylindric, drooping, expanding to a length of over $10 \mathrm{~mm}$, pale ochraceous. Peridium evanescent; calyculus shallow, ochraceous, glossy, spinulose-reticulate inside. Stipe up to $1 \mathrm{~mm}$ long, brown, glossy. Hypothallus conspicuous, membranous, common to a colony. Capillitium ochraceous, attached only to apex of stalk, and expanding into cotton-like loose tangle. Threads 3-6 $\mu \mathrm{m}$ thick plus spines, half-rings and reticulations. Spores pale ochraceous in mass, nearly hyaline by transmitted light, smooth with some scattered warts, 7.5-8.4 $9.5 \mu \mathrm{m}$.

This species has commonly been known as $A$. nutans, but Onsberg (1978) introduced A. obvelata as the correct name.

\section{Ceratiomyxa fruticulosa (Müll.) Macbr.}

2: $3486,3497,3509,3511,3512,3513,3726,3740,3747$, TS 454 , TS 475, TS 481. 11: 3661, 3667, 3669, 3684, 3687, 3689, 3691,3697 , TS 405, TS 416. 18: 3477,3482 . Two collections from submontane rain forest, twenty-two from montane forests. One on litter, the others on decaying wood. Cosmopolitan. One of the most common species, found wherever Myxomycetes occur, from the arctic to the tropics. Reported from almost every part of Africa.

Fructifications composed of white or yellowish pillars, in clusters or forming large crawling colonies up to several centimeters in length, branched in a dendroid fashion or nearly unbranched, branches varying in size, total height $0.5-1.5 \mathrm{~mm}$. Spores situated individually on sharp spines on the surface of the sporophore, hyaline, globose, oval or ellipsoid, smooth or very faintly irregularly reticulate, 6.2$11.8-16 \times 5-6.7-9 \mu \mathrm{m}$ in size.

Cotton blue makes the shape and ornamentation of these totally hyaline spores clearly visible. In eight specimens spores are rather small and almost globose, 6.2-7.8-9.5 x 5.5-7.7-9 $\mu \mathrm{m}$. On the basis of spore size, this kind of variation has been recognized 
as Ceratiomyxa freyana (Meylan 1925), but because of the wide range of variation of $C$. fruticulosa, Kowalski (1975) states that $C$. freyana is insufficiently distinct to warrant its recognition. In our Tanzanian material we compared sporangia of different spore shape and size in regard to other characteristics such as colour, size, shape, amount of branching and growth habit (dendroid or crawling). No correlation was found.

\section{Comatricha elegans (Racib.) G. Lister}

18: 3481 . Specimen from submontane rain forest. On decayed wood. Widely distributed throughout the world. Earlier reports from Africa are from northern and western parts of the continent.

Sporangia gregarious, stipitate, globose, copperbrown, $1.5-2.5 \mathrm{~mm}$ high, ca. $0.3 \mathrm{~mm}$ in diameter. Peridium evanescent, translucent, brownish, small parts of it remaining at the base of sporangia as a collar. Stipe slender, tapering towards the apex, rigid, shiny-black, up to $2 \mathrm{~mm}$ in height. Hypothallus separate or confluent, brown. Columella short, dividing into some stout, primary branches of the capillitium which form by further divisions a dense brownish net of slender, flexuous dividing and anastomosing threads. Only a few spores in the specimen, pale grey by transmitted light, nearly smooth or faintly spinulose or verrucose, $7.5-9 \mu \mathrm{m}$.

The specimen is badly weathered, but the very typical branching of the capillitium makes identification easy.

\section{Comatricha nigra (Pers.) Schroet.}

2: 3746. Specimen from montane forest. On rotten wood. Cosmopolitan. Earlier found in several parts of Africa. No previous records from eastern Africa.

Sporangia gregarious. Head of sporangium ovate to short cylindric, dark brown. Stipe $3-6 \mathrm{~mm}$, hairlike, black, glossy. Hypothallus small, thin, membranous. Columella reaching to the upper part of sporangium. Capillitium rising from all parts of columella, brown, slender, flexuous, branching and anastomosing but forming no surface net. Spores dark brown in mass, pale brown by transmitted light, very minutely warted with a lighter roundish area, 9.510-11 $\mu \mathrm{m}$.

\section{Craterium leucocephalum (Pers.) Ditmar}

11: 3416. 29: 3555, 3624. Collections from montane belt. On living plants and litter. Cosmopolitan. Reported from many parts of African continent and the islands of the Indian Ocean.
Sporangia gregarious, obovate to cylindric, erect, white to beige, total height $0.7-1 \mathrm{~mm}$, diameter $0.3-$ $0.5 \mathrm{~mm}$. Peridium cartilaginous at the base, remaining as a deep cup, fragile above, dehiscence circumscissile or irregular. Stalk orange to light brown, glossy, plicate, translucent by transmitted light, 0.4 $0.5 \mathrm{~mm}$ high. Hypothallus concolorous with the stipe, solitary. Capillitium having hyaline threads and large, white irregular lime knots, in some sporangia massed in center to form a pseudocolumella. Spores in mass brownish black, violaceous brown by transmitted light, minutely spinulose or verrucose with groups of darker warts, $6.5-7.6-9.5 \mu \mathrm{m}$.

\section{Cribraria aurantiaca Schrad.}

2: 3770, 3771, TS 509. 3: 3507. 11: 3649, 3663. Specimens from montane forests on very rotten wood. Widely distributed throughout the world. Records from Africa are from the northem part.

Sporangia gregarious, stipitate, globose, ochraceous brown, total height $1.5-2 \mathrm{~mm}$, diameter $0.3-$ $0.6 \mathrm{~mm}$. Calyculus distinct, radially sulcate, glossy, in some sporangia also concentrically wrinkled. At the margin numerous long connections with a dense peridial net. Nodes of the net numerous, rounded, convex above, branched, forming small meshes with thin, short threads. Granules in the nodes $1-1.5 \mu \mathrm{m}$ in diameter. Stipe brownish black, glossy, furrowed, $0.7-2 \mathrm{~mm}$ long. Spores in mass ochraceous, by transmitted light almost hyaline, smooth or very minutely spinulose, 5-6-7 $\mu \mathrm{m}$.

Colour reactions were tested of calyculus, net, nodes, and spores in 5\% $\mathrm{KOH}$ (see Nannenga-Bremekamp 1964). All but the spores turned purplish, which confirmed the identification. When seen by phase contrast microscopy one or two brilliantly refracting inclusions were visible in the spores of all specimens except No. 3770.

\section{Cribraria cancellata (Batsch) Nann.-Brem.}

syn. Dictydium cancellatum (Batsch) Macbr.

2: $3502,3734,3751,3754$, TS 510, TS 514, TS 517. 11: 3672. 27: 3423 . One collection from lowland rain forest, the others from montane forests. All on decayed wood. Cosmopolitan. Reported from many parts of Africa, but no previous records from eastern Africa.

Sporangia gregarious, stipitate, globose or depressed-globose, umbilicate, nodding, reddish brown or black, $0.5-4 \mathrm{~mm}$ in total height, $0.4-0.8 \mathrm{~mm}$ in diameter. Stipe long and slender, subulate, shining dark brown to black. Peridium largely fugacious, remaining as numerous longitudinal ribs connected by 
slender transverse bands, often irregular at apex. Well-defined but shallow calyculus from the margin of which numerous ribs arise. Dictydine granules on the surface of the peridium dark, ca. $1-1.5 \mu \mathrm{m}$ in diameter. Spores reddish in mass, yellowish by transmitted light, very minutely spinulose, usually with a few dictydine granules attached to the surface; 4.5-6-7 $\mu \mathrm{m}$.

\section{Cribraria microcarpa (Schrad.) Pers.}

2: 3769. 11: 3647. Collections from montane forests. Both on decayed wood. No earlier records from eastern Africa.

Sporangia solitary, tiny, long-stipitate. Head of sporangium globose, $0.1-0.15 \mathrm{~mm}$, red-brown. Cup lacking or very small, net regular, dense, nodes small, hemispherical; dictydine granules 1-1.2 $\mu \mathrm{m}$. Stalk slender, furrowed, red-brown-orange-yellow, transparent by transmitted light. Spores pale ochraceous by transmitted light, minutely and unevenly spinulose, 6-6.7-7.5 $\mu \mathrm{m}$.

Because of their small size, both specimens were overlooked in the field and found first under a dissecting microscope, one among Cribraria aurantia$c a$, the other among Hemitrichia calyculata.

\section{Diderma effusum (Schw.) Morgan}

29: 3620. Specimen from montane belt. On fallen leaves. Cosmopolitan. Reported from several parts of Africa, but not from eastern Africa.

Scattered, effused, partially fused plasmodiocarps, up to $6 \mathrm{~mm}$ long and only $0.1-0.3 \mathrm{~mm}$ thick. Outer peridium eggshell-like, white. Inner peridium separate, membranous, brown, glossy. No columella. Capillitium delicate, scanty, hyaline. Spores copperbrown in mass, pale yellowish brown by transmitted light, very minutely (seen only by oil immersion lens) warted with faint clusters of larger warts, 89-10 $\mu \mathrm{m}$.

\section{Diderma hemisphaericum (Bull.) Hornem.}

Fig. 3

2: 3719. 11: 3419. Collected in montane belt. On plant litter. Cosmopolitan. Reported from many parts of Africa. No earlier records from eastern Africa.

Sporangia gregarious, discoid, depressed above, $1-1.3 \mathrm{~mm}$ in diameter, ca. $0.2 \mathrm{~mm}$ thick, stipitate. Outer layer of peridium on upper surface white, crustaceous, composed of lime granules, inner layer membranous, shining ochre. Stipe $0.2-1.2 \mathrm{~mm}$ long, thick, ochraceous, calcareous, furrowed with wrinkles continuing on lower surface of sporangium and spreading like buttresses to the concolorous hypothallus. Columella large, ochraceous. Capillitium thin, hyaline, rigid, sparcely branching, with conical granules. Spores dark brown in mass, pale ochraceous brown by transmitted light, minutely warted with some clusters of bigger warts, 6.5-7.3-8 $\mu \mathrm{m}$.

\section{Didymium bahiense Gottsb.}

Fig. 14

2: $3708,3716,3711,3715 \mathrm{a}, 3720.29: 3635$, 3557. Collections from montane belt. All on litter. New to Africa.

Sporangia gregarious, stipitate, erect, globose, slightly umbilicate below. Head of sporangium white, $0.4-0.7 \mathrm{~mm}$ in diam. Peridium thin, translucent, membranous, covered with stellate lime crystals. Stipe 0.7-1.2 mm, thin, striate, glossy, orange-brown and translucent above, black and containing granular matter below. Hypothallus brown, discoid, thin, inconspicuous, or in some specimens well developed. Columella-like pseudocolumella flat, discoid, white, charged with small, rounded, lime granules. Capillitium delicate, sparcely branching and anastomosing, brown or hyaline and having small dark knots. Spores dark brown in mass, brown by transmitted light, minutely but distinctly warted with groups of darker warts, 8.5-9.7-11 $\mu \mathrm{m}$.

The discoid white pseudocolumella is the most apparent feature of $D$. bahiense (see Fig. 14). The species has been described from Brazil (Gottsberger 1968) and also found elsewhere in South America (Farr 1976) and even in Europe (Nannenga-Bremekamp 1974) and Japan (Yamamoto 1988). Nannenga-Bremekamp (1972) emended the description. The present specimens have stipes containing granular matter only at the base and are orange and translucent in the upper part, as in her emendation.

\section{Didymium minus (A. Lister) Morgan}

11: 3701. Collection from montane forest. On fallen leaves. Cosmopolitan. Widely distributed in Africa.

Sporangia scattered, stalked, globose, erect, umbilicate below. Head of sporangium about $0.5 \mathrm{~mm}$. Peridium membranous, dark, thickly covered with white stellate lime crystals. Stipe $0.5-0.6 \mathrm{~mm}$, black, furrowed. Hypothallus dark, membranous, thin, but wide. Columella large, dark brown, globose. Capillitium scanty, delicate hyaline, undulating. Spores dark brown in mass, brown by transmitted light, warted with groups of darker warts $9.5-10-11 \mu \mathrm{m}$. 


\section{Didymium nigripes (Link) Fries}

2: 3715b, 3717. 29: 3629, 3630, 3638, 3641. All specimens collected from montane belt. On litter. Cosmopolitan. Reported from many parts of Africa.

Sporangia gregarious, stipitate, erect, globose. Head of sporangium $0.3-0.6 \mathrm{~mm}$. Peridium thin, dark, membranous, covered with white stellate lime crystals. Stipe $1-1.5 \mathrm{~mm}$, black, and filled with refuse matter at base; copper-brown and by transmitted light translucent at upper part. Hypothallus discoid, thin, dark. Columella dark brown, subglobose. Capillitium brown to hyaline, delicate, undulating. Spores dark brown in mass, pale greyish brown in transmitted light, minutely warted, some specimens with groups of bigger warts 8-8.9-9.5 $\mu \mathrm{m}$.

D.nigripes looks superficially the same as $D$. $b a$ hiense. Both were also found in the same kinds of habitats, on litter of different cultivated plants. Once both species grew mixed on the same compost. $D$. nigripes has smaller and paler spores and a quite different columella from that of $D$. bahiense.

\section{Didymium squamulosum (Alb. \& Schw.) Fries}

2: $3442,3712,3718.29: 3621,3625,3626,3631,3633,3637$, 3640,3656 . Collections from montane belt. On fallen leaves and litter. Cosmopolitan. Found in many parts of Africa. No previous records from eastern Africa.

Sporangia gregarious, globose to hemispherical, stipitate, $0.4-0.7 \mathrm{~mm}$ in diameter, up to $1.7 \mathrm{~mm}$ in total height. Peridium membranous, shiny, covered with a thick white crust of stellate lime crystals. Stipe 0.3-1 mm long, stout, furrowed, white, calcareous, spreading at the base into a discoid hypothallus. Columella hemispherical, white, connected to the peridium by a dense, delicate capillitium. Threads of capillitium slender, colourless, wavy, simple. Spores black in mass, violaceous brown by transmitted light, warted, warts clustered in some spores, 7-8.5-10 $\mu \mathrm{m}$.

\section{Fuligo septica (L.) Wiggers}

2: $3500,3505,3752,3759,3763$, TS 479, TS 526, TS 528. Collections from montane forests. In Cupressus lusitanica and Pinus patula stands, on decaying wood, litter, and living plants. Cosmopolitan. One of the most common and widely distributed of Myxomycetes. Not previously reported from eastern Africa.

Aethalia pulvinate, $2-4 \mathrm{~cm}$ broad, yellow. Cortex thick, calcareous, fragile, dehiscence irregular. Capillitium hyaline with yellow nodes. Spores black in mass, grayish brown by transmitted light, minutely spinulose, 6-7.4-10 $\mu \mathrm{m}$, some slightly oval.
Hemitrichia calyculata (Speg.) Farr

Fig. 5

syn. H. stipitata (Massee) Macbr.

2: $3439,3443,3447,3473,3498,3704,3707.3: 3471,3499$, $3506,3515,3516.11: 3414,3433,3451,3648,3653,3660$, 3668, 3681, 3686, 3698, 3702. 12: 3456, 3464. 18: 3492. 27: 3410. 29: $3611,3612,3613,3636$. One collection from lowland rain forest, one from submontane forest, twenty-nine from montane forests. All on decaying wood. Widely distributed in temperate and tropical regions. No previous records from eastem Africa.

Sporangia scattered or in small clusters, stipitate, clavate or turbinate, ochraceous yellow, $1-4.5 \mathrm{~mm}$ tall. Peridium thin, yellow, translucent glossy, evanescent, except for a deep, plicate, calyculus petaloid in margin. Stipe reddish brown to almost black, shiny, furrowed, filled with spore-like cells and refuse matter, height $0.5-2.5 \mathrm{~mm}$. Hypothallus small, concolorous with the stipe. Capillitium elastic, expanding considerably after dehiscence, yellow, branched and anastomosed to form a dense net with few sharp or obtuse free ends; threads, if distinct enough to be counted, with four spirals, smooth, 4 $6.5 \mu \mathrm{m}$ in diameter. Spores yellow in mass, light yellow or almost hyaline in transmitted light, very minutely spinulose, the spinules in most spores arranged to form a reticulum $6.5-7.8-9.5 \mu \mathrm{m}$ in diameter. tion.

This was the most common species in our collec-

\section{Lamproderma arcyrionema Rost.}

Fig. 6

18: 3454. Collection from submontane rain forest. On decayed wood. Cosmopolitan. This species is probably one of the most common species of Lamproderma in tropical and subtropical areas. Reported earlier from northern and western Africa.

Sporangia gregarious, stipitate, globose, steel gray and iridescent, $2-3.5 \mathrm{~mm}$ high, ca. $0.5 \mathrm{~mm}$ in diameter. Peridium thin, translucent, splitting irregularly into small patches except for the base which remains as a collar around the stipe. Stipe black, shining, very slender and long, up to $3 \mathrm{~mm}$, arising from a small, membranous, brownish hypothallus. Columella slender, about one-third to one-half the height of the sporangia, dividing at the apex into some stout main branches which by further division give rise to a dense flexuous capillitium net, with some expansions in the axils. Spores black in mass, grayish brown by transmitted light, very faintly spinulose or warted, with clusters of darker spores, 8-8.75-10 $\mu \mathrm{m}$.

The shiny peridium, collar around the stipe and small, faintly marked spores of the specimen are typical for Lamproderma arcyrionema. Kowalski (1970) 

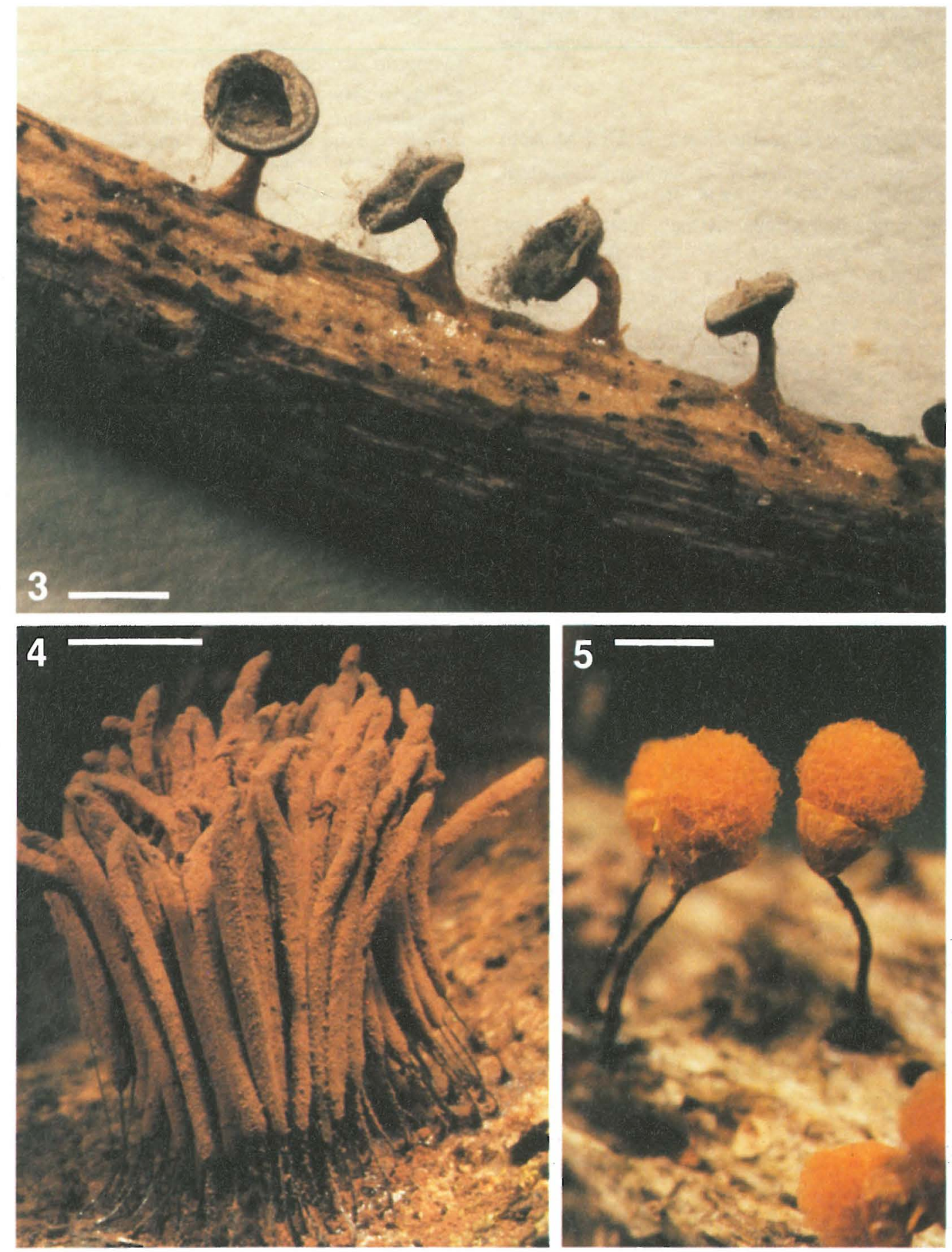

Figs. 3-5. Sporangia of Tanzanian Myxomycetes. 3. Diderma hemisphaericum (No. 3419). Bar =1 mm. 4. Stemonitis smithii (No. 3465). Bar $=2 \mathrm{~mm}$. 5. Hemitrichia calyculata (No. 3439). Bar = $1 \mathrm{~mm}$. 
states that this species has no expanded axils in the capillitium. This specimen, however, has very distinctive expansions (Fig. 6). Neubert et al. (1989) also state that $L$. arcyrionema may have capillitium with triangular expansions.

\section{Lamproderma scintillans (Berk. \& Br.) Morgan}

2: 3714. Specimen from montane belt. On litter. Cosmopolitan. Many records from different parts of Africa.

Sporangia gregarious, stalked, globose, erect. Head of sporangium $0.3-0.4 \mathrm{~mm}$; peridium iridescent in blue and bronze tints. Stipe thin, hair-like, black, 0.8-1 mm long. Hypothallus thin, dark, discoid, rather wide. Columella black, cylindric, truncate, reaching to about the center of the sporangium. Capillitium radiating from the top of the columella, at base hyaline, later straight and dark brown, then undulating and dividing, but only a few anastomoses; tips pale and sharp. Spores dark sepia brown in mass, pale greyish and regularly warted by transmitted light, 8-8.5-9 $\mu \mathrm{m}$.

The specimen is very large. The colour of the sporangia is brilliantly blue at one edge and shining bronze at the other edge of the colony. The shape of blue sporangia is somewhat ovoid compared with the totally globose shape of the bronze ones, so that two species could be suspected. In microscopical examination all proved, however, to belong to the same taxon and the blue sporangia are somewhat immature.

\section{Lycogala epidendrum (L.) Fries}

2: $3496,3713,3765$. 11: 3422. 18: 3478. 27: 3415. One collection from lowland rain forest, one from submontane rain forest, four from montane forests. All on decaying wood. Cosmopolitan. One of the most common Myxomycetes. Distributed widely in Africa. Not previously recorded from eastern Africa.

Aethalia scattered or clustered, brownish gray to almost black, sessile, hemispherical, $2-10 \mathrm{~mm}$ in diameter. Peridium thick, covered with brown scales; dehiscence apical. Pseudocapillitium almost hyaline, attached to the inner side of peridium, branched and anastomosed, consisting of tubular threads with conspicuous transverse folds and wrinkles, 5-20 $\mu \mathrm{m}$ in diameter; free ends numerous, clavate. Spores pinkish grey in mass, yellowish or hyaline in transmitted light, reticulate, $4.5-6.2-8 \mu \mathrm{m}$.

\section{Lycogala exiguum Morgan}

Fig. 7

2: 3508. 3: 3519. 12: 3463. 18: 3487, 3491. Two collections from submontane rain forest, three from montane forests. All on decayed wood. Cosmopolitan. From Africa reported only from northern and western parts.

Aethalia scattered or clustered, subglobose, dark brown to black, $0.5-5 \mathrm{~mm}$ in diameter. Peridium thick, grey, densely covered with pulvinate, black protuberances; dehiscence by apical tear. Pseudocapillitium light yellow to hyaline, tubules arising from the inner surface of the peridium, $2-10 \mu \mathrm{m}$ in diameter, smooth or slightly transversely wrinkled; free ends numerous, clavate. Spores ochraceous in mass, almost hyaline by transmitted light, very delicately reticulate, appearing spinulose in profile, 4-5.3$6.5 \mu \mathrm{m}$.

Lycogala exiguum is very close to, and is often considered a variety of $L$. epidendrum, also widely reported in Africa. L. exiguum is distinguished from L. epidendrum by the smaller aethalia, the somewhat smaller, more faintly marked pseudocapillitium and spores, and the dark, tessellate scales on the cortex (Martin 1967). Eliasson and Sunhede (1980) have shown by SEM examination that the scales, as a matter of fact, are protuberances of the outermost peridial layer. This can also be seen under a light microscope (Fig. 7).

\section{Metatrichia floriformis (Schw.) Nann.-Brem.}

syn. Trichia floriformis (Schw.) G. Lister

12: $3455,3457,3462$. Collections from montane forest. On decayed wood. Widely distributed throughout the world. Earlier reported from northern and central Africa.

Sporangia gregarious, solitary, stipitate, pyriform; two-layered, split into petal-like lobes. Total height up to $3 \mathrm{~mm}$. Stipe ca. $2 \mathrm{~mm}$ long, reddish brown, shiny, furrowed, flattened, translucent above by transmitted light. Hypothallus membranous, small or continuous, concolorous with the stipe. Capillitium consisting of simple elaters, ca. 5-6 $\mu \mathrm{m}$ in diameter at center, tapering gradually to long, slen-

Figs. 6-9 (Right). Microscopical details of Tanzanian Myxomycetes. 6. Lamproderma arcyrionema, expanded axils in capillitium (No. 3454). Bar $=20 \mu \mathrm{m}$. 7. Lycogala exiguum, protuberances of outermost peridium (No. 3508). Bar $=100 \mu \mathrm{m}$. 8. Stemonitis splendens, wide-meshed, regular surface net (No. 3452). Bar $=100 \mu \mathrm{m}$. 9. Stemonitis splendens, two adjacent sporangia with partially fused surface nets (No. 3452). Bar $=500 \mu \mathrm{m}$. 

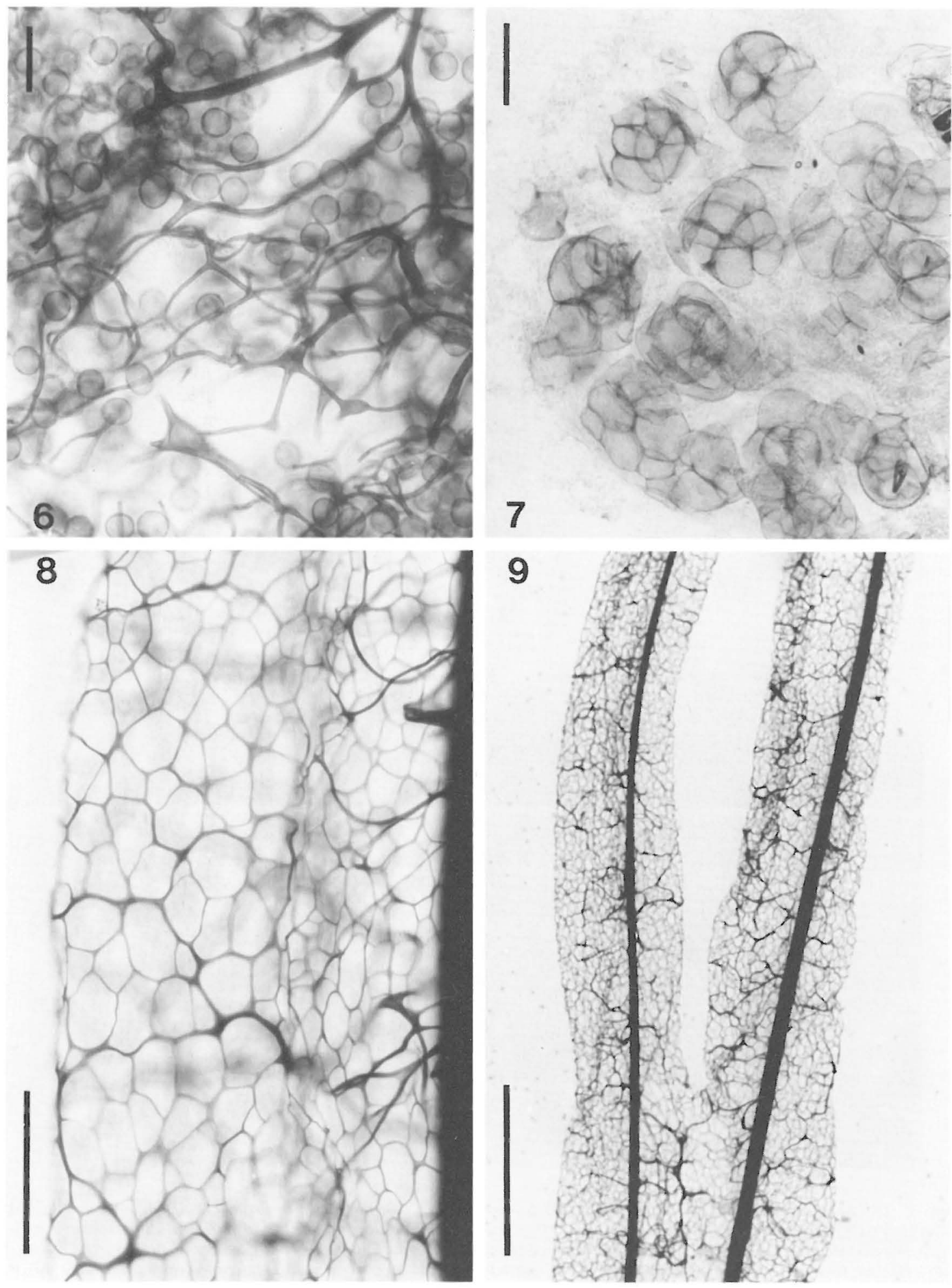

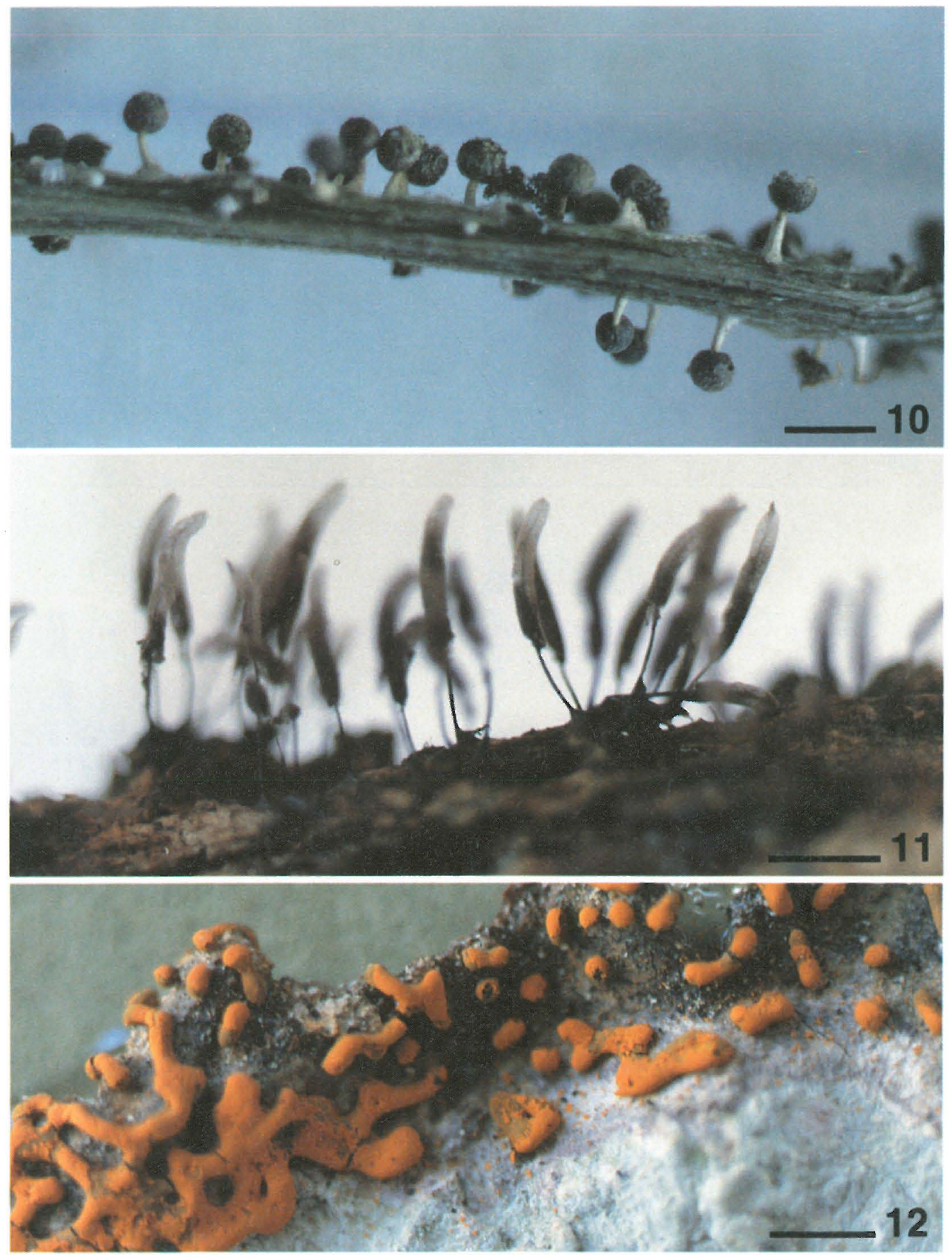

Figs. 10-18 (Above and Right). Sporangia of Tanzanian Myxomycetes. 10. Physarum melleum (No. 3430$).$ Bar $=1 \mathrm{~mm} .11$. Stemonitopsis microspora (No. 3470). Bar $=2 \mathrm{~mm}$. 12. Physarum superbum (No. 3488). Bar $=2 \mathrm{~mm}$. 13. Tubifera bombarda (No. 3685). Bar = $1 \mathrm{~mm}$. 14. Didymium bahiense with flat, discoid pseudocolumella (No. 3716). Bar = $1 \mathrm{~mm}$. 15. Paradiachea cylindrica with iridescent peridium and pale columella (No. 3680). Bar $=1 \mathrm{~mm}$. 16. Pseudoaethalia of Tubifera microsperma (No. 3642). Bar $=2 \mathrm{~mm}$. 17. Physarum bogoriense (No. 3623). Bar $=1 \mathrm{~mm}$. 18. Physarum javanicum (No 3614 ). Bar $=1 \mathrm{~mm}$. 

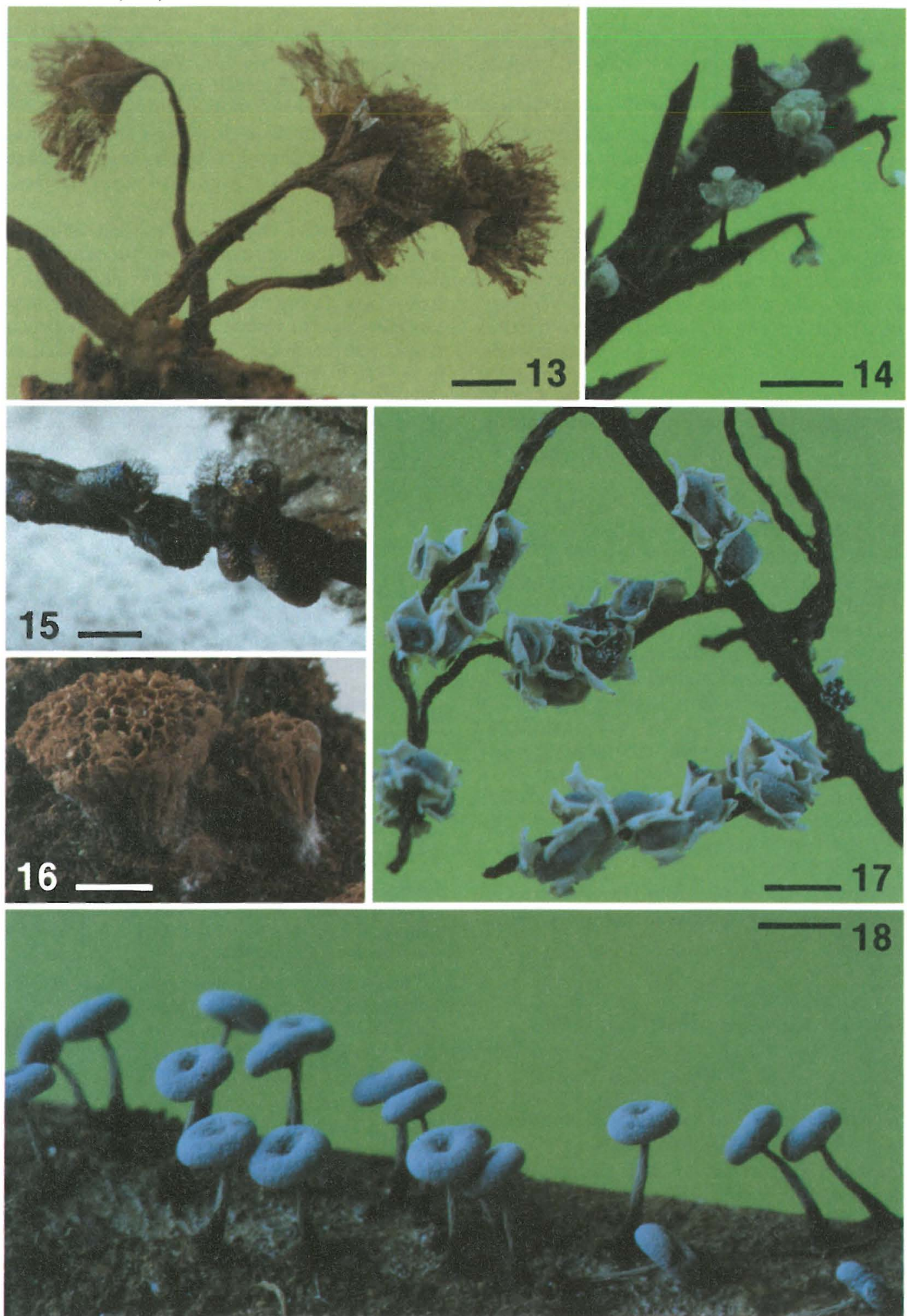
der, acuminate tips. Spores reddish brown in mass, yellow by transmitted light, $8.8-10.4-11.3 \mu \mathrm{m}$ in diameter, very minutely warted.

Nannenga-Bremekamp (1982) suggested that Trichia floriformis should be transferred to Metatrichia. When seen in polarized light, all Trichiaspecies except $T$. floriformis have a birefringent capillitium, whereas the capillitium of Metatrichia does not birefringe. The new combination, Metatrichia floriformis, was later validated (Nannenga-Bremekamp 1985). We checked our Tanzanian specimens in polarized light using permanent slides in Hoyer's medium about half a year old. The capillitium and spores of Metatrichia floriformis showed no birefringence, whereas the capillitial elaters of Trichia favoginea and Hemitrichia calyculata shone brilliantly. In addition, the spores of $T$. favoginea were also birefringing.

\section{Metatrichia horrida B. Ing}

11: 3665 . Collection from montane forest. On decaying wood. Reported earlier from western and southern central Africa.

Sporangia densely aggregate, sessile, cylindrical, $0.4-0.6 \mathrm{~mm}$ in diam and $0.5-0.7 \mathrm{~mm}$ tall. Peridium double, red-brown, iridescent. Dehiscence by a preformed sunken lid. Hypothallus thick, red-brown, common for the colony. Capillitium coiled inside the sporangium like a ball of yarn. Elaters orange-brown by transmitted light, unbranched with few clavate pointed ends, ornamented with spiral bands crowded with long sharp spines; the width of elaters about $6.5 \mu \mathrm{m}$ without spines, $13 \mu \mathrm{m}$ when spines included. Spores red-brown in mass, golden yellow by transmitted light, very minutely spinulose and having a germ pore, 8-9.2-10 $\mu \mathrm{m}$.

This species has been described from Nigeria (Ing 1964). It has been reported also from Angola (Almeida 1974a).

\section{Paradiachea cylindrica (Bilgram) Hertel} Fig. 15

syn. Comatricha cylindrica (Bilgram) Macbr.

11: $3644,3678,3679,3680,3700$, 3703. All collections from montane forests. One on decaying wood, the others on living plants and litter. New to Africa.

Sporangia gregarious in small dense clusters, sessile, ovoid to cylindric. Total height $0.8-1.8 \mathrm{~mm}$, diameter $0.3-0.8 \mathrm{~mm}$. Peridium thin, membranous, strongly iridescent in blue and golden tints, scaling off in upper parts. Hypothallus thin, membranous, common to a colony. Columella pale yellowish, rath- er stout but fragile, extending to near the apex. Capillitium dark brown, rigid, forking and anastomosing with occasional expanded junctions and pale, sharp tips. Spores dark brown in mass, pale grey by transmitted light, with dark, stout warts and rows of warts partially connected by a ridge to form a broken irregular reticulum, 9.5-12.1-14 $\mu \mathrm{m}$. Plasmodium bright yellow.

In Mazumbai on forest litter and living herbs several yellow, robust phaneroplasmodium-looking plasmodia were found. Some were taken to the field station, and during the night they developed through a black phase to become brilliantly iridescent sporangia. Mature specimens were also collected in the field. The characters of the sporangia are very significant, most of all the columella and the ornamentation of the spores. However, the amount of meshes on the spores vary a lot. One specimen (No. 3644), matured in the laboratory, had no reticulation at all, but only some scattered warts and short rows of warts.

Martin \& Alexopoulos (1969) placed the species in the genus Comatricha. The strongly iridescent peridium, however, fits Lamproderma or Diachea. Originally the species was understandably described as Diachea (Bilgram 1905). In that genus, the columella is calcareous. When we looked at the present specimens in polarized light, in some sporangia small birefringent cubes could be seen reminiscent of lime. That is, however, quite different from the strongly calcareous stipe and columella in Diachea. So we consider Hertel (1956) was correct in placing the species in his new genus Paradiachea.

\section{Physarella oblonga (Berk. \& Curt.) Morgan}

3: 3485, 3517. 29: 3617b. All collections from montane forests. On decayed wood. Widely distributed in the tropics of both hemispheres. Previous collections from Africa are western, southern central and southern.

Sporangia gregarious, stipitate, cylindrical, deeply infundibuliform, mostly nodding, ca. $0.5 \mathrm{~mm}$ in diameter, $2-3 \mathrm{~mm}$ in total height. Peridium covered with deposits of yellow lime-granules; dehiscence lobate, exposing the spikes of limy capillitium. Stipe furrowed, reddish brown, darker and broader at the base, arising from a small, membranous, brown hypothallus. Capillitium consisting of numerous, slender, hyaline threads and big, yellow, spine-like processes arising from the peridium and extending to the trumpet-shaped pseudocolumella. Spores almost black in mass, violet-brown or grey-brown by transmitted light, very minutely and unevenly punctate to warted, 7.3-7.8-9 $\mu \mathrm{m}$. 
Physarum bogoriense Racib.

Fig. 17

29: 3623. Specimen collected from montane belt. On litter dump. Reported from several parts of Africa, no previous records from eastern Africa.

Sporangia and short plasmodiocarps scattered to gregarious, sessile with constricted base, $0.5-0.6 \mathrm{~mm}$ in diameter, up to $3 \mathrm{~mm}$ long. Outer peridium thick, double, pale ochraceous outside; and having preformed light lines, along which the peridium ruptures into stellate lobes, so that the white calcareous inner surface becomes visible. A third thin, gray peridial layer surrounds the spore-mass. Hypothallus inconspicuous. No columella. Capillitium dense, hyaline with many large rounded white lime nodes. Spores dark brown in mass, light greyish brown by transmitted light, very minutely spinulose (seen only by oil immersion lens) 7-7.7-8 $\mu \mathrm{m}$.

According to Whitney \& Keller (1982), P. bogoriense is a pantropical species. They described the species based on collections made throughout the tropics and subtropics.

\section{Physarum citrinum Schum.}

2: 3749. Collection from montane forest. On decaying wood. Cosmopolitan. Earlier reports are from southem and southern central Africa.

Sporangia gregarious, stipitate. Head of sporangium globose, flat below, bright sulphur yellow, about $0.6 \mathrm{~mm}$ in diameter. Peridium thin, but having thick calcareous nodes. Stipe stout, orange-white, slightly furrowed, charged with lime, 1-1.2 mm tall. Stipe spreads at top into a small collar. Hypothallus inconspicuous. Columella small, conic or absent. Capillitium a dense hyaline net with many angular bright yellow lime nodes, partally connected in a badhamioid manner. Spores dark sepia brown in mass, light violaceous brown by transmitted light, minutely warted with groups of darker warts, 9.5$10-11 \mu \mathrm{m}$.

\section{Physarum compressum Alb. \& Schw.}

2: 3441, 3709, 3710, 3725. 29: 3616, 3632, 3634. Collections from montane belt. On litter. Cosmopolitan. Reported from many parts of Africa, but no earlicr records from eastern Africa.

Sporangia gregarious, stipitate, laterally compressed, one specimen also having sessile sporangia and short plasmodiocarps. Peridium thin, iridescent or brownish, covered with white lime granules, rupturing lengthwise above. Stipe black, furrowed, frosted with white lime. Hypothallus inconspicuous. No columella. Capillitium hyaline, having white lime nodes, which vary in shape and size. Spores black in mass, brown by transmitted light, globose, spinulose, 9.5-11-12.5 $\mu \mathrm{m}$.

Physarum javanicum Racib.

Fig. 18

29: 3614. Specimen from montane belt, on litter. Earlier reported from eastern and southern Africa.

Sporangia gregarious to scattered, erect, stipitate. Head of sporangium turbinate, umbilicate above, resembling a doughnut, $0.8-1 \mathrm{~mm}$ wide, $0.2-0.4 \mathrm{~mm}$ thick, ash-grey. Peridium thin and encrusted with lime granules. Stipe 1-1.5 mm long, furrowed, frosted with white above, dark and filled with refuse matter at base, continuing into a small discoid hypothallus. No columella. Capillitium dense, having in addition, physaroid, white, irregular lime nodes as tubular spikes connecting the upper and lower surface of the peridium. Spores dark brown in mass, pale purplish gray by transmitted light, very minutely but distinctly spinulose with groups of darker warts 9-9.8$11 \mu \mathrm{m}$. Most spores have a narrow but clearly visible line of dehiscence.

A variety, var. macrosporum, with conspicuous paler fissure on spores, has been described (Lakhanpal \& Mukerji 1981). The spores are, however, bigger than in this specimen.

\section{Physarum melleum (Berk. \& Br.) Massee}

18: $3412,3430,3453$. Collections from submontane rain forests. On fallen leaves and living herbs. Cosmopolitan. Abundant throughout the tropics. Reported earlier from western and southern Africa.

Sporangia gregarious, stipitate, honey yellow to pale orange, globose, $0.5-0.7 \mathrm{~mm}$ in diameter, ca. $1 \mathrm{~mm}$ in total height. Peridium thin, shiny, encrusted with lime granules, irregular or lobate in dehiscence, persistent at base. Columella small, conical, white. Stipe white calcareous, furrowed, tapering upwards. Hypothallus small, yellowish. Capillitium abundant, consisting of slender threads and large, white, angular nodes, which appear yellowish gray by transmitted light. Spores dark brown in mass, light brown by transmitted light, very minutely warted, globose or slightly oval, 7-8.5-10 $\mu \mathrm{m}$.

\section{Physarum mutabile (Rost.) G. Lister}

29: $3622,3627,3639$. Collections from montane belt. On fallen leaves and dumps. Collected from several parts of Africa; no previous reports from eastern Africa. 
Sporangia gregarious, cylindric, stalked but merging to sessile and even short plasmodiocarpous in some parts of the colony. Total height of sporangium $0.8-1 \mathrm{~mm}$, width about $0.5 \mathrm{~mm}$. Peridium thin, grey and charged with white lime granules. Stalk thick, short, yellowish. Hypothallus thin, membranous. Pseudocolumella a thick, white column. Capillitium intricate, with numerous white large lime granules. Spores dark brown in mass, pale violaceous brown by transmitted light, very minutely spinulose with groups of darker warts, 8-9-11 $\mu \mathrm{m}$.

\section{Physarum notabile Macbr.}

3: 3438 . Collection from Ericaceous belt. On a trunk of living Juniperus excelsa. Reported from temperate, subtropical and tropical regions. New to Africa.

Sporangia stipitate or sessile, gregarious or in small clusters, shining white, globose, ca. $0.7 \mathrm{~mm}$ in diameter. Peridium thin, translucent, crusted with large white lime granules, dehiscence irregular or stellate; basal peridium persists as a broad cup. Columella absent. Stipe, when present, stout, up to $1 \mathrm{~mm}$ high, rugose, black, covered with white calcareous granules and filled with refuse matter. Hypothallus pale brown. Capillitium composed of large, angular, white or sometimes bluish nodes and hyaline internodes. Spores black in mass, olivaceous brown by transmitted light, minutely but densely and evenly spinulose, 9.5-10-11 $\mu \mathrm{m}$ in diameter and having a pale line of dehiscence.

Physarum notabile resembles $P$. leucophaeum. Identification was made on the basis of the black stipe frosted with white lime, large angular nodes and relatively dark spores.

\section{Physarum nucleatum Rex}

2: 3728. 18: 3432,3469 . Collections from submontane rain forests. On decayed wood. Distributed widely in tropics of both hemisperes. From Africa reported earlier from northern, westem and southern parts.

Sporangia gregarious, stipitate, globose or subglobose, $0.5-0.7 \mathrm{~mm}$ in diameter, white. Peridium thin, membranous, densely covered with rounded, white lime nodules. Stipe pale yellow to orange, $0.6-$ $2.2 \mathrm{~mm}$ tall, translucent in transmitted light, spreading into a small firm collar in basal portion of peridium. Hypothallus orange, membranous. Capillitium a dense network of hyaline, slender threads connecting white lime nodes, round or elongate in shape. A portion of lime nodes aggregated at center to form a globose, white pseudo-columella. Spores dark in mass, pale violaceous brown by transmitted light, very faintly spinulose, spines partially clustered, 5.5-7.2-9 $\mu \mathrm{m}$.

\section{Physarum nutans Pers.}

2: TS 468, TS 471. 3: 3521. 11: 3675. 18: 3436, 3489. 27: 3420. One collection from lowland rain forest, two from submontane rain forest, four from montane forests. All on decayed wood. Cosmopolitan. Reported from most parts of Africa, but no previous records from eastern Africa.

Sporangia gregarious, stipitate, discoid, white, usually nodding, $0.4-1 \mathrm{~mm}$ in diameter. Peridium thin, membranous, iridescent, covered with lime granules, irregular or lobate in dehiscence, persistent at base. Stipe slender, 1-3 mm long, subulate, rugose, white or yellowish at apex, dark at base, filled with refuse matter. Hypothallus small, dark brown. Capillitium arising from bottom of peridium, consisting of radiating, hyaline threads and small rounded or fusiform, white nodes. Columella absent. Spores blackish brown in mass, violaceous brown or grey-brown by transmitted light, almost smooth or very minutely verrucose, some warts more closely placed, 7-8.4-10 $\mu \mathrm{m}$.

Physarum pezizoideum (Jungh.) Pav. \& Lag. var. pezizoideum

2: 3768. Collection from montane forest. On decaying wood. Widely distributed in Old World tropics, from India to Australia. Reported earlier also from eastem Africa, but the distribution records may refer to either variety.

Sporangia gregarious, stipitate, flat discoid to saucer-shaped, pure white, $1.2-1.5 \mathrm{~mm}$ in diameter, total height $2-4 \mathrm{~mm}$. Peridium membranous, thinly covered with lime granules, breaking irregularly into small patches which remain attached to capillitium, basal portion forming a disc. Stipe slender, subulate, striate, twisted, reddish brown, translucent in transmitted light, 1.5-2.5 mm long and spreading to a small orange disc on basal portion of peridium. Hypothallus small, brownish, membranous. Capillitium consisting of coarse columns filled with lime and connecting the upper and lower surface of the sporangia. No columella. Spores black in mass, dark brown by transmitted light, strongly spinulose, 19-22-24 $\mu \mathrm{m}$ including the up to $2 \mu \mathrm{m}$ long spines.

\section{Physarum pezizoideum var. microsporum Farr}

2: 3721, 3748. 3: 3435. 12: 3458. Collections from montane forests. On decayed wood and leaves. 
Superficially as var. pezizoideum but lacking the orange basal disc. Capillitium is more physaroid, having hyaline threads with small, mostly fusiform, lime nodules. Spores totally different: pale violet brown by transmitted light and minutely spinulose with clusters of more prominent spines, 8-8.6$9.5 \mu \mathrm{m}$.

Farr (1964) described this variety from Zaire. In our Tanzanian material the differences between the two taxa are so obvious that two different species could be suggested. According to Farr $(1964,1976)$ the similarity in sporangial form and intergradation of other characters would preclude separation of the two taxa on a species level.

\section{Physarum psittacinum Ditmar}

3: 3520 . Collection from montane forest. Reported earlier from temperate and tropical regions in Europe, North and South America and Asia. New to Africa.

Sporangia gregarious, stipitate, depressed-globose, ca. $0.8 \mathrm{~mm}$ in diameter, up to $2 \mathrm{~mm}$ in total height. Peridium membranous, iridescent blue, mottled with whitish lime granules, dehiscing irreglularly. Stipe furrowed, orange, limeless, up to $1.5 \mathrm{~mm}$ long, flared basally, tapering upwards. Hypothallus small, membranous, concolorous with the stipe. Capillitium densely reticulate, consisting of hyaline threads and orange angular lime nodes which vary in size. No columella. Spores dark brown in mass, violaceous brown by transmitted light, minutely spinulose, 7-7.2-8.5 $\mu \mathrm{m}$ in diameter.

Specimen mould-infected, but typical characteristics could be found.

\section{Physarum pusillum (Berk. \& Curt.) G. Lister}

11: 3677, 3693. 29: 3628. Specimens from montane belt. On litter and decaying wood. Cosmopolitan. Reported from almost every part of Africa.

Sporangia gregarious, stipitate, erect or somewhat nodding, globose. Head of sporangium white with red-brown base, $0.5-0.7 \mathrm{~mm}$ in diameter. Peridium thin, membranous and encrusted with lime nodules. Stipe slender, subulate, dark copper-brown, glossy, translucent and fibrous by transmitted light. No columella. Capillitium hyaline with rather large, white lime nodes, partially badhamioid. Spores dark brown in mass, pale lilaceous brown by transmitted light, very minutely spinulose with clusters of bigger warts, 9-9.6-10 $\mu \mathrm{m}$.
Physarum superbum Hagelst.

Fig. 12

18: 3488 . Collection from submontane rain forest. On living vine about $1.5 \mathrm{~m}$ above the ground. Reported earlier from the Neotropics and India. New to Africa.

Fructifications plasmodiocarpous, simple or reticulate, laterally slightly compressed, up to some centimeters long, mixed with globose to ovoid, sessile sporangia, bright orange, $0.5-0.6 \mathrm{~mm}$ in diameter. Peridium covered with a thick calcareous crust, breaking into flakes, inner layer thin, membranous, translucent. Capillitium composed of numerous orange, angular or rounded lime nodes and hyaline filaments. Spores black in mass, violaceous brown by transmitted light, almost smooth to delicately verruculose, globose or slightly oval, 7.5-8-9.5 $\mu \mathrm{m}$.

\section{Physarum viride (Bull.) Pers.}

2: $3493,3494,3733,3745,3750.11: 3428,3445,3448$, TS 428b. 12: 3459, 3460, 3461. 13: 3424. 18: 3421. 29: 3619. One collection from submontane forest, all the others from montane forests. All on decayed wood. Cosmopolitan. Reported earlier from many parts of Africa, but no records from eastern Africa.

Sporangia gregarious, stipitate, subglobose to discoid (lenticular), nodding, usually umbilicate below, sometimes depressed also above, $0.3-0.8 \mathrm{~mm}$ in diameter, variable in color, pale to bright yellow, orange or greenish, fading later. Peridium thin, membranous, encrusted with lime granules, dehiscing in small fragments above, leaving floriform lobes below. Stipe $0.8-2 \mathrm{~mm}$ long, slender, often twisted near the apex, varying from gray or yellow to reddish brown above, and darker to black below, lower part filled with refuse matter. No columella. Capillitium a radiating network of hyaline threads and fusiform or rounded, yellow to orange lime nodes arising from the sporangial base. Spores dark brown in mass, violet- or gray-brown by transmitted light, almost smooth or very faintly spinulose with some clusters of bigger warts, 7-8.3-9.5 $\mu \mathrm{m}$.

The wide range of sporangial colour found in this species has led to descriptions of several varieties based on colour only. According to Martin \& Alexopoulos (1969), these merge completely. Our collections include three colour forms (aurantium, incanum and viride) all of which have been earlier reported from the tropics.

\section{Stemonitis axifera (Bull.) Macbr.}

2: $3730,3739,3760,3764$, TS 486. 3: 3484. 11:3656, 3658. Collections from montane forests. On decayed wood. Cosmopo- 
litan. Reported from many parts of Africa, but no previous records from eastern Africa.

Sporangia densely clustered, arising from a membranous hypothallus, stipitate, cylindrical, flexuous, cinnamon brown, 3-11 mm in total height. Peridium evanescent. Stipe black, shining, $1.2-3 \mathrm{~mm}$ tall, one third of the sporangial length. Columella almost reaching the tip of the sporangium, merging into the capillitium to form a slender, large-meshed internal net and a delicate, evenly uniform surface net, meshes rectangular, mostly 3-30 $\mu \mathrm{m}$ in diameter. Spores brown in mass, nearly hyaline by transmitted light, almost smooth 4.5-6-7.3 $\mu \mathrm{m}$.

\section{Stemonitis fusca Roth}

2: 3722,3735 , TS 531. 11: 3650, 3652, 3673, 3696. 18: 3475 . 27: 3411 . One collection from lowland rain forest, one from submontane rain forest, seven from montane forests. Cosmopolitan. Abundant in tropical regions and the most widely distributed and prolific species of Stemonitis. Reported from almost every part of Africa, also from eastern Africa.

Sporangia in large and dense clusters, stipitate, slender, cylindrical, obtuse at apex, narrowed at base, 6-14 $\mathrm{mm}$ in length, fuscous. Peridium fugacious. Stipe black, 1-7 mm long, shining. Hypothallus shining, membranous, brown, confluent. Columella black, reaching to near the sporangial apex, primary branches stout with membranous expansions, forming a large-meshed internal net, ultimate branches united to form a delicate, small-meshed surface net. Spores in mass fuscous, grayish brown by transmitted light, warted-reticulate, 6.3-7.4-9 $\mu \mathrm{m}$.

\section{Stemonitis pallida Wingate}

2: $3723,3731.11: 3670.18: 3483$. One collection from submontane rain forest, three from montane forests. On decaying wood. Reported from many parts of the world. Earlier reports from Africa are from western, southern central and southern parts.

Sporangia in small, gregarious clusters, stipitate, cylindric, $4-7 \mathrm{~mm}$ in total height, violet-brown. Stipe black, shining, $1.5-3 \mathrm{~mm}$ tall, rising from a common, thin, brown hypothallus. Columella tapering upwards and gradually merging into the capillitial net below the apex. Capillitium arising along the entire length of columella, primary branches stout with expansions, surface net small-meshed, meshes polygonal with spine-like free ends, 4-25 $\mu \mathrm{m}$ in diam. Spores dark brown in mass, violaceous brown by transmitted light, very minutely punctate, 5.5-6.3$7.3 \mu \mathrm{m}$.

Stemonitis smithii Macbr.

Fig. 4

11: 3645,3664 . 12: 3465. Collections from montane forests. On decayed wood. Widely distributed in temperate and tropical regions. Reported earlier from western and central Africa.

Sporangia in small, dense clusters, stipitate, erect, tapering towards apex and base, cinnamon brown, 4-7 $\mathrm{mm}$ in total height. Peridium evanescent. Stipe ca. 2-3 mm long, black, shining. Hypothallus confluent. Columella extending nearly to the the apex of the sporangium, merging to the capillitial net above. Capillitium branching and anastomosing to form a loose internal net with stout branches and a distinct surface net with small meshes. Spores brown in mass, pale gray-brown by transmitted light, smooth, 3.7-4.3-6.3 $\mu \mathrm{m}$.

Stemonitis splendens Rost.

Figs. 8-9

2: $3449,3727,3753.13: 3452$. 18: 3450. One collection from submontane rain forest, four from montane forests. All on decaying wood. Cosmopolitan. Reported from many parts of Africa, also from eastern Africa.

Sporangia densely clustered, forming large colonies, stipitate, cylindrical, violaceous or fuscous brown, $10-20 \mathrm{~mm}$ in total height. Stipe $2-6 \mathrm{~mm}$ long, slender, black, shining, arising from a common, membranous, brownish hypothallus. Peridium evanescent. Columella shining black, reaching nearly to the apex of the sporangium. A slender capillitium rising from the entire columella at almost regular intervals. Internal net large-meshed and simple with membranous junctions. Surface net regular (Fig. 8), wide-meshed, with angular to rounded meshes, 10 $100 \mu \mathrm{m}$ in diameter; sometimes nets of sporangia next to each other fused partly together (Fig. 9). Spores brown in mass, yellowish brown in transmitted light, minutely warted, $6.5-8-9.5 \mu \mathrm{m}$ in diameter, germination pore large and distinct.

Table 1 (Right). Myxomycete species of 1988 and 1989 expeditions to Tanzania and their known distribution in Africa according to the literature. Those in boldface are new to Africa. N.AF. = northern Africa; SAHEL = Sahel Africa; W.AF. = western Africa; C.AF. = central Africa; E.AF. = eastern Africa; S.C.AF. = southern central Africa; S.AF. = southern Africa; M. \& I. = Madagascar \& adjacent islands; COSM. = cosmopolitan. 


\begin{tabular}{|c|c|c|c|c|c|c|c|}
\hline & \multicolumn{3}{|c|}{ VEGETATION BELT } & \multirow[b]{2}{*}{ Eric. } & \multicolumn{3}{|c|}{ HABITAT } \\
\hline & lowl. & subm. & mont. & & wood & litt. & plant \\
\hline Arcyria affinis & & & 1 & & 1 & & \\
\hline Arcyria cinerea & & 5 & 23 & 1 & 26 & 3 & \\
\hline Arcyria denudata & & 1 & 23 & & 23 & 1 & \\
\hline Arcyria globosa & & & 1 & & & 1 & \\
\hline Arcyria insignis & 1 & 1 & 6 & & 7 & 1 & \\
\hline Arcyria obvelata & & & 3 & & 3 & & \\
\hline Ceratiomyxa fruticulosa & & 2 & 22 & & 23 & 1 & \\
\hline Comatricha elegans & & 1 & & & 1 & & \\
\hline Comatricha nigra & & & 1 & & 1 & & \\
\hline Craterium leucocephalum & & & 3 & & 1 & 1 & 1 \\
\hline Cribraria aurantiaca & & & 6 & & 6 & & \\
\hline Cribraria cancellata & 1 & & 8 & & 9 & & \\
\hline Cribraria microcarpa & & & 2 & & 2 & & \\
\hline Diderma effusum & & & 1 & & & 1 & \\
\hline Diderma hemispaericum & & & 2 & & & 2 & \\
\hline Didymium bahiense & & & 7 & & & 7 & \\
\hline Didymium minus & & & 1 & & & 1 & \\
\hline Didymium nigripes & & & 6 & & & 6 & \\
\hline Didymium squamulosum & & & 11 & & & 11 & \\
\hline Fuligo septica & & & 8 & & 6 & 2 & 1 \\
\hline Hemitrichia calyculata & 1 & 1 & 29 & & 31 & & \\
\hline Lamproderma arcyrionema & & 1 & & & 1 & & \\
\hline Lamproderma scintillans & & & 1 & & & 1 & \\
\hline Lycogala epidendrum & 1 & 1 & 4 & & 6 & & \\
\hline Lycogala exiguum & & 2 & 3 & & 5 & & \\
\hline Metatrichia floriformis & & & 3 & & 3 & & \\
\hline Metatrichia horrida & & & 1 & & 1 & & \\
\hline Paradiachea cylindrica & & & 6 & & 1 & 4 & 3 \\
\hline Physarella oblonga & & & 3 & & 3 & & \\
\hline Physarum bogoriense & & & 1 & & & 1 & \\
\hline Physarum citrinum & & & 1 & & 1 & & \\
\hline Physarum compressum & & & 7 & & & 7 & \\
\hline Physarum javanicum & & & 1 & & & 1 & \\
\hline Physarum melleum & & 3 & & & & 2 & 1 \\
\hline Physarum mutabile & & & 3 & & & 3 & \\
\hline Physarum notabile & & & & 1 & & & 1 \\
\hline Physarum nucleatum & & 2 & 1 & & 3 & & \\
\hline Physarum nutans & 1 & 2 & 4 & & 7 & & \\
\hline Physarum pezizoideum & & & 5 & & 5 & & \\
\hline Physarum psittacinum & & & 1 & & 1 & & \\
\hline Physarum pusillium & & & 3 & & 1 & 2 & \\
\hline Physarum superbum & & 1 & & & 1 & & \\
\hline Physarum viride & & 1 & 14 & & 15 & & \\
\hline Stemonitis axifera & & & 8 & & 8 & & \\
\hline Stemonitis fusca & 1 & 1 & 7 & & 9 & & \\
\hline Stemonitis pallida & & 1 & 3 & & 4 & & \\
\hline Stemonitis smithii & & & 3 & & 3 & & \\
\hline Stemonitis splendens & & 1 & 4 & & 5 & & \\
\hline Stemonitopsis microspora & & 2 & & & 2 & & \\
\hline Stemonitopsis typhina & 1 & 2 & 2 & & 5 & & \\
\hline Trichia favoginea & & & 1 & & 1 & & \\
\hline Tubifera bombarda & & & 2 & . & 2 & & \\
\hline Tubifera microsperma & & & 1 & & 1 & & \\
\hline No. of specimens (297) & 7 & 31 & 257 & 2 & 234 & 59 & 7 \\
\hline No. of species (53) & 7 & 19 & 48 & 2 & 40 & 21 & 5 \\
\hline
\end{tabular}


Stemonitopsis microspora (A. Lister) Nann.Brem. Fig. 11

syn. Stemonitis microsperma B. Ing.

18: 3470,3504 . Collections from submontane rain forests. On decayed wood. Earlier collections from Africa only from the northern part.

Sporangia gregarious or in small clusters on common membranous hypotallus, stipitate, cylindric, tapering towards the apex, violaceous brown, $3-4.5 \mathrm{~mm}$ in total height. Peridium evanescent. Stipe 1-1.5 mm long, black, shining. Hypothallus confluent, membranous, blackish. Columella tapering upwards, branching radially below the apex of the sporangium. Primary branches slender, arising horizontally from the columella. Surface net exists only in basal part of sporangia, meshes $6-15 \mu \mathrm{m}$; numerous free ends in upper part. Spores violet-brown in mass, pale grayish brown by transmitted light, under immersion objective banded-reticulate, $3.7-4.3-4.5 \mu \mathrm{m}$.

\section{Stemonitopsis typhina (Wiggers) Nann.-Brem.} syn. Comatricha typhoides (Bull.) Rost.

3: 3501. 11: TS 402. 18: 3466, 3479. 27: 3425. One collection from lowland rain forest, two from submontane rain forest, two from montane forests. All on decayed wood. Cosmopolitan. Reported from many parts of Africa. No previous records from eastern Africa.

Sporangia scattered to gregarious, stipitate, cylindric, obtuse, erect, at first silvery-grey from the presence of the soon-evanescent peridium, then violet-brown, 3-8 $\mathrm{mm}$ in total height. Stipe black, shining, covered with a silvery sheet, up to half the total height. Hypothallus membranous, glossy, more or less continuous. Peridium membranous, occasionally persistent as irregular patches or as basal collars or cups. Columella reaching nearly to the apex of sporangium. Capillitium rising from the entire columella. Primary branches a little thicker than the successive branches which form a dense and intricate reticulum with numerous spike-like free ends, no surface net. Spores lilac-brown in mass, pale grayish in transmitted light, marked with a few distinct clusters of warts, otherwise smooth, 5-6.1-7 $\mu \mathrm{m}$.

\section{Trichia favoginea (Batsch) Pers.}

2: 3503. Collection from montane forest (Grevillea robusta stand). On decayed wood. Widely distributed in mountains of the tropics. Reported earlier from northern, western and central Africa.

Sporangia crowded, sessile, clavate, up to $2 \mathrm{~mm}$ tall. Peridium membranous, ochraceous to olivaceous brown, shining, dehiscence mostly by rupturing of the peridium in the upper portion. Hypothallus confluent, membranous, marked with vein-like brown deposits. Capillitium yellow, consisting of numerous free elaters, 5-6.5 $\mu \mathrm{m}$ in diameter, marked with spiny, spiral bands and having pointed, short apices. Spores ochraceous in mass, bright yellow by transmitted light, 11.3-12.5-14 $\mu \mathrm{m}$ in diameter, reticulate with irregular bands, about $1.25 \mu \mathrm{m}$ in width.

\section{Tubifera bombarda (Berk. \& Br.) Martin} Fig. 13

11: 3685,3692 . Specimens from montane forests, on decaying wood. Reported from tropical Asia and the Caribbean area. New to Africa.

Sporangia in gregarious fascicles of 1-10 on common stalk, horn-shaped, brown, slightly iridescent. Total height 5-7 mm. Hypothallus thin, brown, inconspicuous. Peridium thin, smooth, membranous, brown, iridescent, cup-shaped, $0.5-0.7 \mathrm{~mm}$ wide about $1 \mathrm{~mm}$ high. From inside of the cup, rigid, brown filaments about $1 \mathrm{~mm}$ long grow out, resembling a brush. The filaments are tubular, spinulose and with bulbous swellings. Stipe rugose, furrowed, dark brown, $2.5-5 \mathrm{~mm}$ tall. Spores brown in mass, pale ochraceous by transmitted light, finely and incompletely reticulate, $5-6.1-7 \mu \mathrm{m}$.

\section{Tubifera microsperma (Berk. \& Curt.) Martin}

Fig. 16

11: 3642. Collection from montane forest. On decaying wood. Earlier records are from temperate and tropical regions of North and South America and Asia. New to Africa.

Many scattered, seemingly stipitate small brown pseudoaethalia $1.2-7 \mathrm{~cm}$ in diameter. Individual sporangia crowded, cylindrical, somewhat angular, 2-3 mm tall, 0.6-0.9 mm wide, sessile on columnlike, thick, dark brown hypothallus. Peridium thin, membranous, iridescent brown. No capillitium or columella. Spores brown in mass, pale ochraceous in transmitted light, incompletely reticulate, 5-5.3$5.5 \mu \mathrm{m}$.

Table 2 (Right). Number of Myxomycete specimens collected in Tanzania in 1988 and 1989, by vegetation belts (Niemelä 1988) and habitats. Lowl. = lowland, mainly rainforest, altitude under $800 \mathrm{~m}$; subm. = submontane rainforest, altitude $800-1000 \mathrm{~m}$; mont. = montane forest, altitude $1000-2400(3000) \mathrm{m}$; Eric. = Ericaceous belt, altitude above $2400 \mathrm{~m}$; wood = on decayed wood; litt. $=$ on litter; plant $=$ on living plants. 


\begin{tabular}{|c|c|c|c|c|c|c|c|c|c|}
\hline & N.AF. & SAHEL & W.AF. & C.AF. & E.AF. & S.C.AF. & S.AF. & M. \& I. & $\cos M$ \\
\hline Arcyria affinis & & & & $\mathrm{x}$ & & & & & \\
\hline Arcyria cinerea & $\mathrm{x}$ & & $\mathrm{x}$ & $\mathrm{x}$ & & $\mathrm{x}$ & $\mathrm{x}$ & $\mathrm{x}$ & $\mathrm{x}$ \\
\hline Arcyria denudata & $x$ & & $x$ & $\mathrm{x}$ & & $x$ & $x$ & $x$ & $x$ \\
\hline Arcyria globosa & & & $x$ & & & $x$ & & & \\
\hline Arcyria insignis & $x$ & & $x$ & $x$ & & $x$ & $x$ & & $\mathrm{x}$ \\
\hline Arcyria obvelata & $\mathrm{x}$ & & $\mathrm{x}$ & $\mathrm{x}$ & & $\mathrm{x}$ & $\mathrm{x}$ & & $\mathrm{x}$ \\
\hline Ceratiomyxa fruticulosa & $x$ & & $x$ & & $x$ & $x$ & $x$ & $x$ & $\mathrm{x}$ \\
\hline Comatricha elegans & $x$ & & $x$ & & & & & & \\
\hline Comatricha nigra & $x$ & & $\mathrm{x}$ & & & $\mathrm{x}$ & $\mathrm{x}$ & & $\mathrm{x}$ \\
\hline Craterium leucocephalum & $\mathrm{x}$ & & $\mathrm{x}$ & & & $\mathrm{x}$ & & $\mathrm{x}$ & $\mathrm{x}$ \\
\hline Cribraria aurantiaca & $x$ & & & & & & & & \\
\hline Cribraria cancellata & $x$ & & $x$ & & & $x$ & $x$ & & $x$ \\
\hline Cribraria microcarpa & & & $x$ & & & $x$ & & $x$ & \\
\hline Diderma effusum & $\mathrm{x}$ & & $x$ & $\mathrm{x}$ & & & $x$ & $\mathrm{x}$ & $\mathrm{x}$ \\
\hline Diderma hemispaericum & $\mathrm{x}$ & & $x$ & $x$ & & $x$ & $x$ & $\mathrm{x}$ & $x$ \\
\hline \multicolumn{10}{|l|}{ Didymium bahiense } \\
\hline Didymium minus & $\mathrm{x}$ & & $\mathrm{x}$ & $\mathrm{x}$ & $\mathrm{x}$ & $x$ & $x$ & $x$ & $x$ \\
\hline Didymium nigripes & $x$ & & $x$ & & & $\mathrm{x}$ & $\mathrm{x}$ & $\mathrm{x}$ & $\mathrm{x}$ \\
\hline Didymium squamulosum & $x$ & & $\mathrm{x}$ & & & $x$ & $x$ & $x$ & $\mathrm{x}$ \\
\hline Fuligo septica & $x$ & & $x$ & & & & $x$ & $x$ & $x$ \\
\hline Hemitrichia calyculata & $\mathrm{x}$ & & $\mathrm{x}$ & $\mathrm{x}$ & & $x$ & & $x$ & \\
\hline Lamproderma arcyrionema & $x$ & & $x$ & & & & & & $\mathrm{x}$ \\
\hline Lamproderma scintillans & $\mathrm{x}$ & & $\mathrm{x}$ & $\mathrm{x}$ & & $\mathrm{x}$ & $x$ & & $\mathrm{x}$ \\
\hline Lycogala epidendrum & $x$ & & $\mathrm{x}$ & $x$ & & $x$ & $x$ & $x$ & $\mathrm{x}$ \\
\hline Lycogala exiguum & $x$ & & $x$ & & & & & & $x$ \\
\hline Metatrichia floriformis & $\mathrm{x}$ & & & $\mathrm{x}$ & & & & & \\
\hline Metatrichia horrida & & & $\mathrm{x}$ & & & $x$ & & & \\
\hline \multicolumn{10}{|l|}{ Paradiachea cylindrica } \\
\hline Physarella oblonga & & & $\mathrm{x}$ & & & $x$ & $\mathrm{x}$ & & \\
\hline Physarum bogoriense & $x$ & & $x$ & & & $x$ & $x$ & $x$ & \\
\hline Physarum citrinum & & & & & & $\mathrm{x}$ & $\mathrm{x}$ & & $\mathrm{x}$ \\
\hline Physarum compressum & $x$ & & $x$ & $x$ & & $x$ & $x$ & $x$ & $x$ \\
\hline Physarum javanicum & & & & & $x$ & & $x$ & & \\
\hline Physarum melleum & & & $\mathrm{x}$ & & & & $\mathrm{x}$ & $x$ & $\mathrm{x}$ \\
\hline Physarum mutabile & & & $\mathrm{x}$ & & & $\mathrm{x}$ & $\mathrm{x}$ & $x$ & \\
\hline \multicolumn{10}{|l|}{ Physarum notabile } \\
\hline Physarum nucleatum & $x$ & & $\mathrm{x}$ & & & & $x$ & & \\
\hline Physarum nutans & $x$ & & $x$ & & & $x$ & $\mathrm{x}$ & $x$ & $\mathrm{x}$ \\
\hline Physarum pezizoideum & & & $x$ & & $x$ & $x$ & $x$ & & \\
\hline \multicolumn{10}{|l|}{ Physarum psittacinum } \\
\hline Physarum pusillium & $\mathrm{x}$ & & $\mathrm{x}$ & $\mathrm{x}$ & & $\mathrm{x}$ & $\mathrm{x}$ & $x$ & $\mathrm{x}$ \\
\hline \multicolumn{10}{|l|}{ Physarum superbum } \\
\hline Physarum viride & $x$ & & $x$ & & & $x$ & $x$ & $x$ & $x$ \\
\hline Stemonitis axifera & $x$ & & $\mathrm{x}$ & $x$ & & & $\mathrm{x}$ & $x$ & $\mathrm{x}$ \\
\hline Stemonitis fusca & $\mathrm{x}$ & & $\mathrm{x}$ & $\mathrm{x}$ & $\mathrm{x}$ & $\mathrm{x}$ & $x$ & $x$ & $x$ \\
\hline Stemonitis pallida & & & $\mathrm{x}$ & & & $x$ & $x$ & & \\
\hline Stemonitis smithii & & & $\mathrm{x}$ & $\mathrm{x}$ & & & & & \\
\hline Stemonitis splendens & $\mathrm{x}$ & & $\mathrm{x}$ & $\mathrm{x}$ & $\mathrm{x}$ & $\mathrm{x}$ & $\mathrm{x}$ & $x$ & $\mathrm{x}$ \\
\hline Stemonitopsis microspora & $x$ & & & & & & & & \\
\hline Stemonitopsis typhina & $x$ & & $\mathrm{x}$ & $x$ & & $x$ & $x$ & $x$ & $x$ \\
\hline Trichia favoginea & $\mathrm{x}$ & & $\mathrm{x}$ & $\mathrm{x}$ & & & & & \\
\hline \multicolumn{10}{|l|}{ Tubifera bombarda } \\
\hline Tubifera microsperma & & & & & & & & & \\
\hline
\end{tabular}


According to Nelson et al. (1982) T. microsperma can be distinguished from all other Tubifera species by crater-like markings on the inner peridial surface. In our specimens such markings could be seen very clearly, but not on all parts of the peridia.

\section{Results and discussion}

Half of the species we collected are cosmopolitan (see Table 1). Seven are new to Africa. All except six are new to eastern Africa, and none have previously been recorded from Tanzania. Many species which we encountered in Tanzania are distributed widely across the African continent, with the exception of the very dry regions.

Martin \& Alexopoulos (1969) and Farr (1976) assert that most Myxomycetes are cosmopolitan. Farr (1976) listed the following species as the most widely distributed and common: Ceratiomyxa fruticulosa, Metatrichia vesparium (Batsch) Nann.-Brem., several species of Arcyria, Lycogala epidendrum or Lycogala exiguum or both, Physarum nutans, P. viride, Physarella oblonga, Comatricha typhoides, two or three species of Stemonitis. We found all of these except Metatrichia vesparium. Six of the seven species we report as new to Africa have been found in the Neotropics (Farr 1976) and three of them in India (Lakhanpal \& Mukerji 1981).

All three expeditions took place during the rainy seasons (a short rainy period in November-December and a longer period in March-May), and we searched for Myxomycetes in promising sites in dif- ferent vegetation belts. Most of the fructifications were found in the montane belt (1 000-2 400 [3 000] m) (Table 2). Venkataramani \& Kalyanasundaram (1986) having made similar observations of Indian Myxomycetes, state that "Myxomycetes generally seek a somewhat temperate climate even in the tropics; hence they occur in greater abundance in the hills than in the plains, during cool seasons rather than warm and when rainfall is moderate rather than heavy." Our data show, however, no significant difference in the occurrence of Myxomycetes during the period of heavier rains (May) as compared to the period of more moderate rains (December). Alexopoulos (1970) also states that Myxomycetes are less abundant in rain forests than in temperate forests in rainy periods.

Most of the species were found on decaying wood, but many specimens also occur on litter or even on living plants. Graphic representation (Fig. 19) shows how in the Tanzanian material specimens of order Physarales most often occur on litter whereas those of order Licheales were found only on decaying wood.

On the basis of the high endemism in flora in East African mountains (Hedberg 1968, Hamilton 1989, Lovett 1989) we supposed that undescribed myxomycete species might be found, but all the specimens could be determined as existing described species. Also Eliasson (1991), in his study on the Myxomycetes of the Hawaiian Islands, states that restricted endemism appears to be an unknown phenomenon among Myxomycetes.

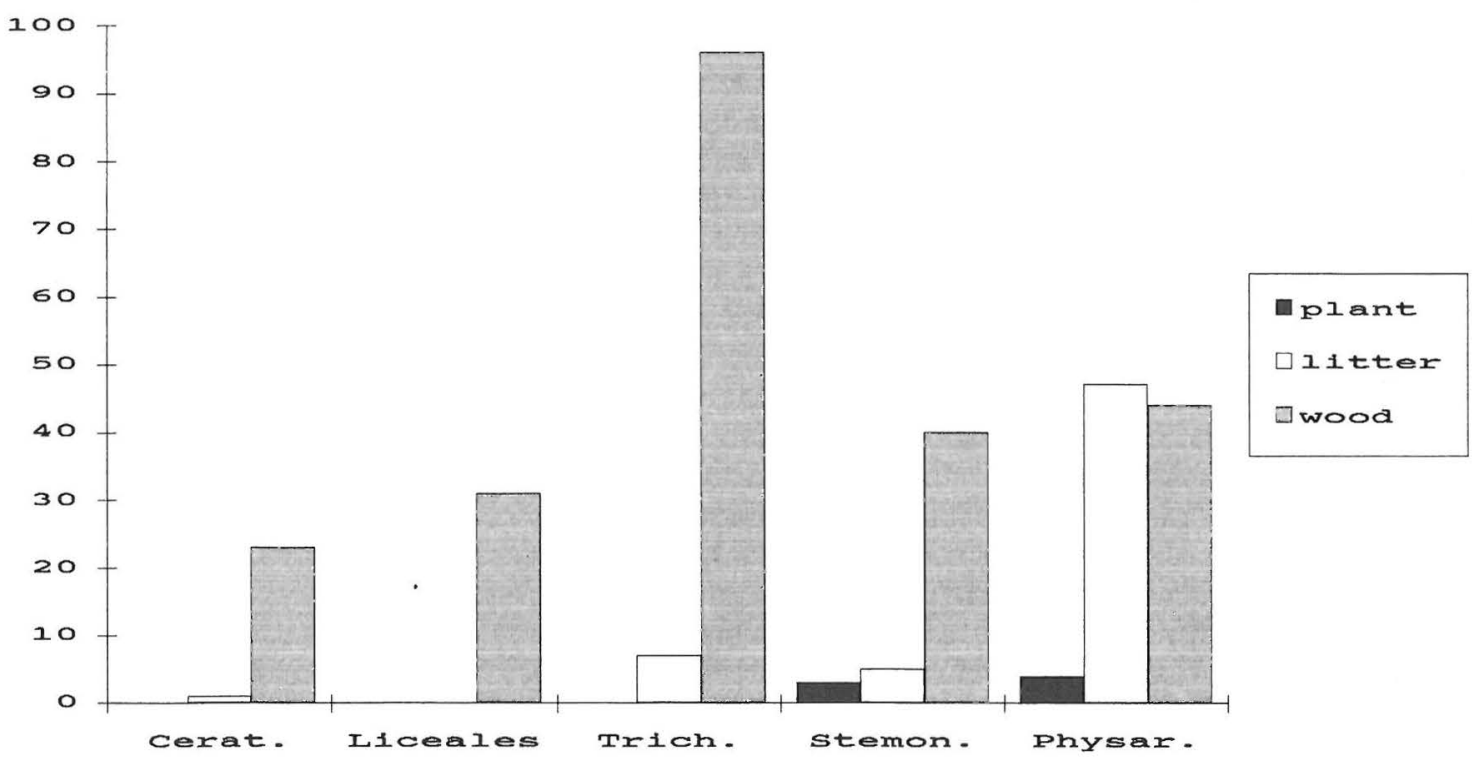

Fig. 19. Number of specimens of different orders on different substrates. 
Acknowledgements. We want to thank Prof. Tamás Pócs (Sokoine University of Agriculture, Morogoro) and Mrs. Sarolta Pócs for help and guidance during all the three expeditions, Mrs. N.E. Nannenga-Bremekamp (Holland) for comments and help in identification, the Academy of Natural Sciences of Philadelphia for the loan of Arcyria globosa specimens and Miss Vanamo Salo for SEM photos. Dr. Carol Norris revised the English text. For financial support we thank the Academy of Finland, the Finnish International Development Agency (FINNIDA) and University of Helsinki. For making it possible for us to publish colour photos we thank British Airways who diminished our travelling expenses by offering us a free flight from Dar es Salaam to London (24th April 1991).

\section{References}

Alexopoulos, C. 1970: Rain forest Myxomycetes. In: Odum, H. (ed.), A tropical rain forest, pp. 21-23. - U.S. Atomic Energy Commission.

Almeida, M. 1973: Contribuição para o conhecimento dos Myxomycetes de Angola 1. - Bol. Soc. Broteriana 47:277-297.

Almeida, M. 1974a: Contribuição para o conhecimento dos Myxomycetes de Angola 2. - Bol. Soc. Broteriana 48:187-203.

Almeida, M. 1974b: Contribuição para o conhecimento dos Myxomycetes de Moçambique. - Bol. Soc. Broteriana 48:205-210.

Bañares Baudet, A. \& Beltrán Tejera, E. 1987: Adiciones a la flora micológica Canaria.V. - Actas VI. Simp. Nac. Bot. Cript.: 201-211.

Bañares Baudet, A., Beltrán Tejera, E. \& Wildpret de la Torre, W. 1986: Contribución al estudio micológico de los pinares de Tamadaba (Gran Canaria). II. Myxomycota, Ascomycotina y Basidiomycotina (Tremellales y Aphyllophorales). - Vieraea 16:119-135.

Bañares Baudet, A., Beltrán Tejera, E., Loada Lima, A. \& León Arencibia, M.C. 1987: Contribución al studio de la flora micológica del Monte de Aguas y Pasos (Los Silos, Tenerife). II. - Lazaroa 10:229-242.

Beltrán Tejera, E. 1975: Notas sobre los Myxomycetes presentes en el Archipiélago Canario. - Vieraea 6:17-24.

Beltrán Tejera, E., Bañares Baudet, A., León Arencibia, M.C. \& Losada Lima A. 1987: Contribución al estudio de la flora micológica del Monte de Aguas y Pasos (Los Silos, Tenerife). I. - Actas VI. Simp. Nac. Bot. Cript.: 213-224.

Beltrán Tejera, E., Bañares Baudet, A., Rodigues-Armas, L., Losada Lima, A. \& Leon Arencibia, M.C. 1989: Contribución al estudio de la flora micológica del monte Aguas y Pasos (Los Silos, Tenerife). III. - Docum. mycol. 76:41-58.

Bilgram, H. 1905: Diachea cylindrica, a new species of Mycetozoa. - Proc. Acad. Philadelphia 57:524.

Bresadola, J. \& Saccardo, P.A. 1899: Fungi Congoenses. Bull. Soc. Roy. Belgique 38:152-169.

Buyck, B. \& Rammeloo, J. 1983: Diderma (Physarales, Myxomycetes), Echinosteliales et Stemonitales (Myxomycetes). - Flore illustrée des champignons d'Afrique Centrale 11:201-244, pl. 36-43.

Champion, C.L. \& Beltrán Tejera, E. 1980: Catálogo preliminar de los Myxomycetes de Canarias. - Vieraea 9:153-182.
Dixon, P.A. 1959: Myxomycetes of Ghana I. Stemonitis and Comatricha. - J. W. Afr. Sci. Ass. 5:101-104.

Doidge, E. 1950: The South African fungi and lichens to the end of 1945. - Bothalia 5:1-1094.

Duthie, A.V. 1917a: South African Myxomycetes. - S. Afr. J. Sci. 14:456-460.

Duthie, A.V. 1917b: African Myxomycetes. - Trans. Roy. Soc. S. Afr. 6:297-310.

Eliasson, U. 1991: The myxomycete biota of the Hawaiian Islands. - Mycol. Res. 95:257-267.

Eliasson, U. \& Sunhede, S. 1980: External structure of peridium, pseudocapillitium and spores in the myxomycete genus Lycogala Adans. - Bot. Notiser 133:351-361.

Farquharson, C. \& Lister, G. 1916: Notes on South Nigerian Mycetozoa. - J. Bot. (London) 54:121-133.

Farr, M. 1959: O.F. Cook's Myxomycete collection from Liberia and the Canary Islands. - Lloydia 22:295-301.

Farr, M. 1964: Physarum pezizoideum and P. javanicum. Brittonia 16:339-341.

Farr, M. 1976: Myxomycetes. - Flora Neotropica Monogr. 16:1-304.

Faurel, L., Feldmann, J. \& Schotter, G. 1965: Catalogue des Myxomycètes de l'Afrique du Nord. - Bull. Soc. Hist. Nat. Afr. N.S. 55:7-35.

Faurel, L. \& Schotter, G. 1965: Notes Mycologiques 6. Sur quelques champignons coprophiles d'Afrique Equatoriale. - Cah. Maboké 3:123-132.

Gill, L.S. \& Onyibe, H.I. 1986: Phytosociological studies of epiphytic flora of oil palm (Elaeis guineensis Jacq.) in Benin City, Nigeria. - Feddes Repert. 97:691-695.

Gonzales Luis, M.D. \& Beltrán Tejera, E. 1987: Contribución al estudio micológico del Monte de Agua García y Cerro del Lomo, Tenerife. - Vieraea 17:369-391.

Gottsberger, G. 1968: Myxomyceten aus Bahia und Goiás. - Nova Hedwigia 15:361-368.

Gràcia, E. 1986: Tres Mixomicets de la Costa D'Ivori. — Fol Bot. Misc. 5:141-147.

Hamilton, A.C. 1989: Distribution of tree species in the East Usambara forests. In: Hamilton, A.C. \& Bensted-Smith, R. (eds.), Forest conservation in the East Usambara Mountains, Tanzania, pp. 227-230. - IUCN, Gland \& Cambridge.

Härkönen, M. 1981: Gambian Myxomycetes developed in moist chamber cultures. - Karstenia 21:21-25.

Hedberg, 0. 1968: Origin of the afroalpine flora. In: Vuilleumier, F. \& Monasterio, M. (eds.), High altitude tropical biogeography, pp. 443-468. - Oxford Univ. Press, New York.

Hertel, R. 1956: Taxonomia de Comatricha Preuss em. Rost. (Myxophyta). - Dusenia 7:341-350.

Ing, B. 1964: Myxomycetes from Nigeria. - Trans. Brit. Mycol. Soc. 47:49-55.

Ing, B. 1967: Myxomycetes from Sierra Leone. - Trans. Brit. Mycol. Soc. 50:549-553.

Ing, B. \& Hnatiuk, R.J. 1981: Myxomycetes of Aldabra atoll. - Atoll Res. Bull. 249:1-10.

Ing, B. \& McHugh, R. 1968: Myxomycetes from Nigeria II. - Trans. Brit. Mycol. Soc. 51:215-220.

Kowalski, D.T. 1970: The species of Lamproderma. - Mycologia $62: 411-620$.

Kowalski, D.T. 1975: The Myxomycete taxa described by Charles Meylan. - Mycologia 67:448-494.

Lakhanpal, T. \& Mukerji, K. 1981: Taxonomy of the Indian Myxomycetes. - Bibl. Mycol. 78:1-530. J. Cramer, Vaduz. 
Lister, A. 1925: A monograph of the Mycetozoa. Ed. 3., revised by G. Lister. - 296 pp., 222 pls. Witherby, London.

Lovett, J.C. 1989: The Botanical importance of the East Usambara forests in relation to other forests in Tanzania. In: Hamilton, A. \& Bensted-Smith, R. (eds.) 1989, Forest conservation in the East Usambara Mountains, Tanzania, pp. 207-212. - IUCN, Gland \& Cambridge.

Maire, R., Patouillard, N. \& Pinoy, E. 1926: Myxomycètes de l'Afrique du Nord. - Bull. Soc. Hist. Nat. Afr. Nord $17: 38-43$.

Malençon, G. \& Bertault, R. 1967: Champignons du Maroc. - Bull. Soc. Sci. Nat. Phys. Maroc 47:237-281.

Martin, G. 1967: Lycogala exiguum. - Mycologia 59:155160.

Martin, G. \& Alexopoulos, C. 1969: The Myxomycetes. $560 \mathrm{pp}$. Univ. Iowa Press, Iowa City.

Meylan, C. 1925: Note sur divers Myxomycètes de Jura et des Alpes. - Bull. Soc. Vaud. Sci. Nat. 56:65-74.

Nannenga-Bremekamp, N.E. 1964: Notes on Myxomycetes VII. - Acta Bot. Neerl. 13:133-147.

Nannenga-Bremekamp, N.E. 1968: Notes on Myxomycetes XIV. Remarks on the delimitation of some Arcyria species. - Proc. Kon. Nederl. Akad. Wetensch. C 71:31-40.

Nannenga-Bremekamp, N.E. 1972: Notes on Myxomycetes XVIII. A new Didymium and some comments on the Didymium species with long-stalked sporangia. - Proc. Kon. Nederl. Akad. Wetensch. C 75:352-363.

Nannenga-Bremekamp, N.E. 1974: De Nederlandse Myxomyceten. - 440 pp. K.N.N.V., Zutphen.

Nannenga-Bremekamp, N.E. 1982: Notes on Myxomycetes XXI. The use of polarized light as an aid in the taxonomy of the Trichiales. - Proc. Kon. Nederl. Akad. Wetensch. C 85:541-562.

Nannenga-Bremekamp, N.E. 1985: Notes on Myxomycetes XXII. Three new species, two new families and four new combinations. - Proc. Kon. Nederl. Akad. Wetensch. C 88:121-128.

Nelson, R., Scheetz, R. \& Alexopoulos, C. 1982: Taxonomic studies in the Myxomycetes. V. Significance of peridial and spore ornamentations in the genus Tubifera, with a revised key to the species. - Mycologia 74:541-548.

Neubert, H., Nowothy, W. \& Baumann, K. 1989: Myxomycetes aus der Bundesrepublik Deutschland V. - Carolinea 47:25-46.

Niemelä, T. 1988: Itä-Afrikan vuoristojen metsåt ja sademet- sät. Summary: East African montane forests and rain forests. In: Erkkilä, J. \& Kuuluvainen, T. (eds.), Tropiikin metsät. — Silva Carelica 12:57-72.

Onsberg, P. 1978: Notes on Danish Myxomycetes 2. Arcyria obvelata: a new name for Arcyria (Trichia) nutans. Mycologia 70:1284-1286.

Patouillard, N. 1897: Additions au catalogue des champignons de la Tunisie. - Bull. Soc. Mycol. France 13:197-216.

Patouillard, N. 1928: Contribution à l'étude des Champignons de Madiagascar. - Mem. Acad. Malgache 6:1-49.

Patouillard, N. \& de Lagerheim, G. 1895: Champignons de l'Équateur. - Bull. Soc. Mycol. France 11:205-234.

Rammeloo, J. 1973: Contribution à la connaissance des Myxomycètes du Maroc (1re note). - Bull. Soc. Sci. Nat. Phys. Maroc 53:31-35.

Rammeloo, J. 1981a: Diderma (Physarales, Myxomycetes) Flore illustrée des champignons d'Afrique centrale 8-9: 135-169, pl. 23-31.

Rammeloo, J. 1981b: Five new Myxomycete species (Trichiales) from Rwanda. - Bull. Natl. Plantentuin België 51:299-230.

Rammeloo, J. (ed.) 1986: Icones Mycologicae 111-130. 20 pl. Jard. Bot. Natl. Belgique. Meise.

Robbrecht, E. 1974: The genus Arcyria Wiggers (Myxomycetes) in Belgium. - Bull. Jard. Bot. Nat. Belgique. 44:303-353.

Schweinitz, L.D. 1822: Synopsis fungorum Carolinae superioris. - Schr. Naturforsch. Ges. Leipzig 1:20-131.

Venkataramani, R. \& Kalyanasundaram, I. 1986: Ditribution and ecology of Myxomycetes in India. - Proc. Indian Acad. Sci. (Plant Sci.) 96:289-301.

Wakefield, E. 1912: Nigerian Fungi. - Bull. Misc. Inform. 1912: 141-144.

Whitney, D. \& Keller, H. 1982: A new species of Badhamia, with notes on Physarum bogoriense. - Mycologia 74: 619-624.

Wildpret, W. \& Beltran, E. 1974: Contribución al estudio de la flora micológica del Archipiélago Canario. - Anal. Inst. Bot. Cavanilles 31:5-18.

Yamamoto, Y. 1988: Index Myxomycetum Japonicorum. 133 pp. Aki.

Received on 29 April 1991 